\title{
Early Sino-Vietnamese Lexical Data and the Relative Chronology of Tonogenesis in Chinese and Vietnamese
}

\author{
MarkJ. Alves \\ Montgomery College (USA) \\ mark.alves@montgomerycollege.edu
}

\begin{abstract}
Vietnamese has numerous early-era Chinese loanwords with ngang and huyền tones, which in Middle Chinese loanwords correspond to the pingsheng level tone category, for words that should have sắc or nặng tones, corresponding to the Middle Chinese non-level qusheng departing tone category. ${ }^{1}$ It is proposed that this layer of Early Sino-Vietnamese represents borrowing of Chinese words in the period after which Old Chinese had lost final *-s and prior to tonogenesis in Viet-Muong, thus leading to words with the level-tone category when tones emerged in Viet-Muong. This paper provides 60 items of Early Sino-Vietnamese that exemplify this phenomenon of ngang/huyền tones in qusheng words, but also 120 items exemplifying the previously noted reversal of sắc/nặng and hỏi/ngã tones between Early Sino-Vietnamese and later Sino-Vietnamese (the formalized readings of Chinese characters). Altogether, this allows for an overall relative chronology of the development of tones in both Sinitic and Vietic.
\end{abstract}

\section{Keywords}

Sino-Vietnamese - Chinese loanwords - tonogenesis

\section{Introduction}

Haudricourt's (1954b) hypothesis of Vietnamese tonogenesis was that Vietnamese tones could be shown to be associated with former final consonants: in native Vietnamese vocabulary, Proto-Austroasiatic final fricatives *-s/*-h correspond to the Vietnamese hỏi and ngã tones, while final *-? is associated with the sắc and nặng tones (see Table 3). He also showed that these tone categories could be seen in Chinese loanwords in Vietnamese (Haudricourt 1954a), which similarly demonstrated a connection between

1 The terminology for tones in Vietnamese and Chinese historical phonology create challenges in both presentation and comprehension of the issues, as noted by reviewers of this paper. In general, I refer to tones in native, non- Chinese Vietnamese vocabulary and early Chinese loanwords before tonogenesis in Vietnamese using Vietnamese tone names (ngang, huyền, sắc, nặng, hỏi, ngã), but those in Chinese and later Sino-Vietnamese words, which fully follow Chinese tone patterns, using the Chinese historical phonological terms (ping, shang, qu, ru, yin, yang). It is not simple to keep both systems in mind according to the situation, and I hope the method I have used will be sufficiently clear to readers. 
tones and earlier final consonants in Chinese. In Chinese historical phonological terms, Old Chinese (OC hereafter) final *-? is associated with shangsheng tones, and OC final *-s is associated with qusheng tones. The two types of tonogenesis became evident in multiple layers of Chinese loanwords in Vietnamese. In support for OC *-? as a source of the shangsheng tone category, Mei (1970) noted how earlier and later layers of Chinese loanwords appear to alternate between Vietnamese hỏi/ngã and sắc/nặng tones, corresponding to Middle Chinese shangsheng and qusheng categories respectively. Over the decades since those publications, the correspondences between these final consonants and tone categories have been shown to be quite regular, as will be discussed more fully in Section 2.1.

However, in Wang's (1948:63, 76-77 and 1958:380-381) groundbreaking articles on Sino-Vietnamese (SV hereafter) historical linguistics, he noted how some Chinese loanwords in Vietnamese had ngang and huyền tones (corresponding to Middle Chinese (MC hereafter) pingsheng category tones) rather than the expected sắc and nặng tones (qusheng category tones). He offered no phonological explanation but categorized these as nativized forms following Vietnamese pronunciation, what he termed 越化 yuè huà 'Vietnamized', which suggests that these were loanwords modified later after borrowing from Chinese, a category that has remained in Vietnamese historical linguists' studies.

Alves (2005) presented similar instances among grammatical morphs of Chinese origin, including prepositions, measure words/classifiers, and connective words. As in Wang's data, a subset of these grammatical lexemes consists of colloquial words with ngang and huyền, while their later literary SV (LSV hereafter) readings had sắc and năng tones (comparable to level pingsheng and contour qusheng tone categories respectively). In this dataset, the spoken grammatical words have the Vietnamese huyền tone (marked by falling tone diacritics on main vowels), ${ }^{2}$ corresponding to the lower register yangping tone in the Chinese historical phonological tradition, in general, a non-contour-tone category. In contrast, the literary readings, which generally are bound rather than free morphemes, have Vietnamese nặng tones (marked by a dot under main vowels), which correspond to the lower register yangqu tone, a contourtone category. Examples are shown in Table 1. Alves also provided no explanation to account for the disparity in tones in Vietnamese, other than to say it is 'nativized' and most likely borrowed via literary transmission (Alves 2005:324-325).

TABLE 1 Sino-Vietnamese Function Words with Huyền instead of Nặng tones

\begin{tabular}{llll}
\hline Gloss & Chinese & \multicolumn{2}{l}{ Spoken VietnameseStandard readings } \\
\hline category & 類 lèi & loài & loại \\
for; because & 為 wèi & vì & vị \\
self; from & 自 zì & tù̀ & tự \\
outside & 外 wài & ngoài & ngoại \\
allotted duty; part & 分 fèn & phần & phận \\
measure, to & 量 liàng & lường & lượng
\end{tabular}

2 Throughout this paper, Vietnamese orthography, Quốc Ngũ, will be used rather than IPA transcription, somewhat like the use of pinyin for Mandarin Chinese. This orthography is convenient, it allows readers to consult dictionaries, and using the orthography precludes the choice of transcribing one regional accent versus another.

Moreover, the Romanized alphabet is reasonably accessible to readers of English, and the tone diacritics in the system are iconic. Tone categories are also presented in Section 2.1. As a national language, Vietnamese has numerous resources readily available to provide additional detail of Vietnamese phonology. 
However, the substantial number and variety of function words that were borrowed from Chinese into Vietnamese demonstrate a more intense contact scale of linguistic borrowing, not borrowing merely from sociolinguistically influential Vietnamese literati (in a similar vein as Thomason and Kaufman's typology of language contact (1988:75-76)). Phan (2013:347-352) argues that such grammatical Chinese vocabulary in Vietnamese represents an adstratum, the remnants of a now non-existent Chinesespeaking community in that region. Moreover, these items appear not to be from the later period of LSV words, but rather belong to the layer of first millennium loanwords. If they were from the later period, the pingsheng tones on words with sonorant initials would be of the upper yin register and have ngang tones instead of huyền tones of the lower yang register (e.g. non-existent *loai instead of Vietnamese loài 'category') (cf. Wang 1948:54, Phan 2013:95-97, 273-274). The age of these items will be discussed in Section 5 .

I have assembled an unpublished database of several hundred potential Chinese loanwords rated medium to high certainty from the Late Old Chinese (LOC) to Early Middle Chinese (EMC) period, the layer called Early Sino-Vietnamese (ESV) (see Section 2). In that data, several dozen of these doublets of pingsheng and qusheng loanwords were identified. That is, the ESV words had the level tones ngang and huyền, but the LSv tone categories of these words have contour sắc or nặng tones. This additional lexical data further strengthens the claim that this pattern constitutes a systematic phonological change. Over time, while gathering more lexical items in this category of Chinese loanwords in Vietnamese, I have considered several hypotheses to explain the pattern, as shown in Table 2.

The first hypothesis is untenable as the data is sufficient in quantity and consistency that these cannot be considered haphazard aberrations in small numbers of sporadically borrowed words. As for the second hypothesis, Wang (1948) raised the issue of 'nativized' vocabulary, that is, Chinese lexemes modified to fit Vietnamese phonology after being borrowed and generally later than the MC era. However, this cannot be considered viable in light of current understanding of tonogenesis: there are no patterns of changes from level to non-level tones in Vietnamese historical phonology, nor was there a phonological environment in Vietnamese that could have caused the tone categories to shift from non-level to level. In the third hypothesis, Wang (2006) hypothesized that some Chinese words with qusheng tone words did not have final fricatives, the feature that has been claimed to correspond with this tone category. However, as shown in subsequent sections, what Wang presented as data for irregularity in Vietnamese in fact corresponds systematically to multiple strata of Chinese loanwords from different periods (see Table 17 showing examples of triplets). ${ }^{3}$ In the fourth hypothesis, Jia (unpublished notes) has noted a couple dozen instances in Pinghua and Tuhua Chinese of words with pingsheng category tones for what should

TABLE 2 Hypotheses for the alternation between ESV ngang/huyền tones and LSV sắc/nặng tones

1. Random alternations due to loanword intake process

2. Nativized vocabulary in the post-SV period (cf. Wang 1948)

3. Loanwords belonging to one of two types of qusheng words lacking final fricatives in OC (Wang 2006)

4. Instances of pingsheng tones for qusheng words in regions of Southern Chinese, such as Pinghua (p.c. Jia Fangzhi)

5. Evidence of a period of loss of final *-s between LOC and E MC (Pulleyblank 1962 and Zhu 20o9)

3 I only make claims with respect to Sino-Vietnamese data. As for the data for other languages in Wang's paper and Wang's overall hypothesis of different types of qusheng words in Chinese, that is beyond the scope of this paper. 
have qusheng tones. Some of these words are the same as those in ESv data, but a majority are not, so this is not lexical sharing between those groups and the Chinese spoken in northern Vietnam. Whether this can be shown to be a regional tendency and relevant to ESV vocabulary remains to be seen, but regardless, that data is limited and does not affect the main claims of this paper.

Rather than the above hypotheses, considering historical phonological circumstances in both Chinese and Vietnamese, the explanation with the most supporting evidence is as follows: these ESV items with ngang/huyền tones for what are LSv qusheng tone words were borrowed at an intermediary stage in which Sinitic ${ }^{4}$ had lost final fricatives ${ }^{*}$-s and ${ }^{*}$-h and before Vietic had undergone tonogenesis, resulting in level tones in these words. A stage in the development from the end of OC to MC in which final fricatives, which correspond to later qusheng tones around 3rd century CE was originally proposed by Pulleyblank in $1962^{5}$ and revisited later by Zhu (2009 and 2015). The ESV data presented in this paper can support this claim of the process and relative timing of tonogenesis in both Sinitic and Vietic. It thus provides not only support for the historical phonological hypothesis but also of the history of SiniticVietic language contact in the first millennium CE at the time of tonogenesis (before, during, and after) in both speech communities.

The current study presents over 190 early Chinese loanwords in Vietnamese with tonal patterns contrasting with those LSv words borrowed during the Late Middle Chinese (LMC) period. The data supports theories of Haudricourt (1954b) of Vietnamese tonogenesis, Pulleyblank (1962) of final *-s in OC in qusheng words, and Mei (1970) of final *-? and shangsheng words, as shown through patterns of alternations between qusheng and shangsheng tones in ESV and LSV. The data also includes over 60 ESV words with the above-mentioned unexpected ngang and huyền tones in words which later have sắc/năng tones in the MC era LSV (noted in Alves (2016) as a feature of some ESV words). These ESv items (a) clarify the relative timing of the borrowing of doublets in relation to the order of phonological changes in OC, (b) verify that Vietic developed tones later than Sinitic did (and thus somewhat later than Haudricourt originally proposed), and (c) support the presence of a large, long-term Chinese-speaking community in northern Vietnam (i.e. Phan's (2013) Annamese Chinese) through the first millennium CE prior to independence of northern Vietnam from a Chinese administration.

The rest of this paper presents the following: (1) an updated view of tonogenesis in the history of Sinitic and Vietic considering Sino-Vietnamese lexical data, (2) the periods of Sinitic loanwords in Vietic and relevant phonological characteristics of the different strata, (3) explanation of the two types of tonal phenomena noted, and (4) implications of the data and concluding thoughts. In the Appendix, all 190plus items are presented in tables according to phonological patterns, as explained in Section 3 .

\section{An Updated View of the Periods of Tonogenesis in Sinitic and Vietic}

A crucial point to make about Sinitic-Vietic contact is that both language groups have been reconstructed with the finals ${ }^{*}-2,{ }^{*}$-s, and ${ }^{*}$-h, all segments relevant to tonogenesis in both. This situation appears to

\footnotetext{
4 The term 'Sinitic' is used here to refer to the larger speech community that connected both OC and EMC prior to major subbranching of Chinese dialect groups later. It is also parallel with the term Vietic, which similarly refers to the ancestral speech community of modern Vietnamese prior to the major differentiation of Viet-Muong and other groups of Vietic.

5 I must thank Guillaume Jacques for sharing Pulleyblank's article with me. It was crucial in my ability to make this connection between the ESV data and phonological changes from OC to MC.
} 
have had the effect of allowing Vietic speakers to borrow said segments in OC-era and EMC-era words with substantial consistency. These aspects are described further in Sections 2.1 and 2.2.

\subsection{Tonogenesis in Vietic}

As noted, Vietnamese tones are known to correspond to the loss of final consonants, namely, the final fricatives *-h and *-s and final glottal stop *-1 seen in Austroasiatic etyma. ${ }^{6}$ While a comparison of reconstructed Proto-Austroasiatic forms and the related Vietnamese words shows there is not complete consistency, the weight of evidence is sufficient to maintain Haudricourt's hypothesis from several decades ago. The full range of Vietnamese tones and comparative samples in Proto-Vietic and Proto-Austroasiatic are shown in Table 3. In it, the categories of final sonorants, fricatives, and voiceless stops constitute one parameter, while initial consonant voicing is another parameter which divides the categories by tone height.

Notably, in Shorto's (2006) 2,00o Proto-Austroasiatic reconstructions, ${ }^{7}$ while there are many instances of the nặng tone on words with final -p/-t/-k, there are noticeably fewer instances of nặng tone corresponding to a Proto-Austroasiatic etymon with final glottal stop. Conversely, there are numerous instances of Vietnamese nặng tone words which are Chinese loanwords originally with final glottal stop, dozens of which are shown in Tables D, E, F, and G in the Appendix. Thus, SV lexical data provides evidence for Haudricourt's hypothesis of tonogenesis in Vietnamese as well as in Chinese, as discussed in subsequent sections.

Another impact of this hypothesis is an account of tones differing between doublets from earlier and later layers of Chinese loanwords. In the Chinese historical phonological tradition, OC final glottal stop and final *-s are reconstructed for words which have the shangsheng and qusheng categories respectively. In SV doublets borrowed in the two periods of Late MC (LMC hereafter) versus LOC and EMC, there has been a seeming reversal (cf. Mei 1970, Pulleyblank 1978, Sagart 1986, etc.). Chinese words borrowed with final *-? (the shangsheng category) in the earlier period eventually developed sắc and nặng tones in

TABLE 3 Vietnamese Tones and Austroasiatic Comparanda

\begin{tabular}{|c|c|c|c|c|c|c|c|c|}
\hline Tone & Ngang & Huyền & Hỏi & Ngã & Sắc & Nặng & Sắc & Nặng \\
\hline Gloss & bird & turn back & to split & nose & $\operatorname{dog}$ & husked rice & hair & gall \\
\hline Vietnamese & chim & về & chẻ & mũi & chó & gạo & tóc & mật \\
\hline Proto-Vietic & *-ci:m & *ve:r & ${ }^{*} \mathrm{cch}$ & *murs & *?a-cว:? & r-ko:? & *-suk & mәс \\
\hline Proto-AA & * $\operatorname{cim}$ & *wir & $\begin{array}{l}{ }^{*} \mathrm{cih} ; \\
{ }^{*} \mathrm{ci \partial h}\end{array}$ & $\begin{array}{l}\text { *muuh; } \\
{ }^{*} \text { muus }\end{array}$ & $\operatorname{cop}$ & ${ }^{*} \mathrm{rk}[\mathrm{aw}] ?$ & $\begin{array}{l}\text { *suk; } \\
\text { *suək }\end{array}$ & *k.mət \\
\hline Finals & \multicolumn{2}{|c|}{ Sonorants } & \multicolumn{2}{|c|}{ Fricatives } & $?$ & & \multicolumn{2}{|l|}{ Stops } \\
\hline
\end{tabular}

6 The descriptions of tonogenesis in this article are largely based on phonemes and syllable shapes. The actual process likely involved the secondary phonation effects related to the consonants rather than the consonants themselves directly causing tone. For a more precise phonetic account of the process of Vietnamese tonogenesis, see Thurgood (2002). See also Sagart (1986) and Zhu (2009) for a more detailed account of phonetic aspects of Chinese tonogenesis.

7 Shorto used the term 'Proto-Mon-Khmer'. 
Vietnamese, but the same etyma borrowed after the loss of finals and after tonogenesis in both Sinitic and Vietic later developed the hỏi and ngã tones (the Chinese qusheng category): the reverse occurred among qusheng category words in Chinese stemming from words with earlier final *-s. Another way of describing the situation is as follows: the expected Vietnamese tones in MC words with shangsheng tone categories are hỏi and ngả tones, while those with qusheng categories have sắc and nặng tones. This is the case for many thousands of standard Sino-Vietnamese readings of Chinese characters that belong to the LSV layer. In the Esv layer, conversely, shangsheng words have sắc and năng tones, and qusheng words have either hỏi and ngã tones or ngang and huyền tones. This is shown in the highlighted cells in Table 4.

The phonetic situation was undoubtedly more complex..$^{8}$ Vietnamese tones, as do many languages in Mainland Southeast Asia, have a variety of phonation features, such as glottalization, breathiness, and the like, which played a part in both tonogenesis and registrogenesis (cf. Alves (1995), Brunelle and Kirby (2016)). As for Chinese, Sagart $(1986,1988)$ posited that Middle Chinese tones had secondary features, including distinctions in length, glottalization, and creakiness, before the height split which doubled the original four tone categories to eight (cf. Phan (2013:89-91) for further refinement of Sagart's model). While it is difficult to say exactly what impact this had on the borrowing of Sinitic words into Vietic during this period, there is no substantial evidence of impact. That is, EMC words with these hypothesized

TABLE 4 Tone categories of OC, ESV, and LSV (Alves 2016:269)

\begin{tabular}{|c|c|c|c|c|}
\hline Comparative Categories & A (level) & B (rising) & C (departing) & D (entering) \\
\hline $\begin{array}{l}\text { Chinese rhyme table } \\
\text { categories }\end{array}$ & 平 píng & 上 shǎng & 去 qù & 入 rù \\
\hline$O C$ & $\begin{array}{l}\text { final vowels or } \\
\text { sonorants }\end{array}$ & final *-? & final *-s & final ${ }^{*}-\mathrm{p},{ }^{*}-\mathrm{t},{ }^{*}-\mathrm{k}$ \\
\hline Proto-Vietic & $\begin{array}{l}\text { final vowels or } \\
\text { sonorants }\end{array}$ & final *-? & final ${ }^{*}$-s or ${ }^{*}$-h & final ${ }^{*}-\mathrm{p},{ }^{*}-\mathrm{t},{ }^{*}-\mathrm{k}$ \\
\hline Height/register & Yin $\quad$ Yang & Yin Yang & Yin $\quad$ Yang & Yin Yang \\
\hline$E S V$ & ngang huyền & sắc nặng & $\begin{array}{ll}\text { hỏi } & \text { ngã } \\
\text { ngang } & \text { huyền }\end{array}$ & sắc nặng \\
\hline$L S V$ & ngang huyền & hỏi ngã & sắc nặng & sắc nặng \\
\hline
\end{tabular}

8 Polysyllabicity appears not to have had a significant impact on the issues of tone in Chinese loanwords in Vietnamese (though polysyllabicity in Vietic languages has impacted reconstructions of OC, as in Baxter and Sagart (2014)). Based on comparative data with southern Vietic languages, Ferlus (2004) has reconstructed disyllables in Vietic (using the term 'VietMuong, which is here considered a branch of Vietic). Masaaki (2015) has provided textual evidence of presyllables in Vietnamese. Data on Southern Vietic languages shows them to be sesquisyllabic, in which words first have one unstressed, phonologically reduced syllable followed by a stressed syllable. In these sesquisyllabic Vietic languages, tone occurs only on the stressed syllable. Whether Archaic Vietnamese at the stage when presyllables remnants still existed also exhibited this phenomenon of tone solely on stressed syllables is unclear. Regardless, presyllabic material in late Vietic and Ancient Vietnamese apparently had no major impact on ESV and LSV tones, though there are a few cases of unexpected tone height that could be the result of such phonological material. Details for this phenomenon are not yet available, and a fuller study of the matter of polysyllabicity in both Sinitic and Vietic at various points of language contact would be required to clarify the matter: this is clearly beyond the scope of this paper and, again, appears to have had no significant impact on the claims in this paper. 
TABLE $5 \quad$ Eras of Chinese Qusheng Tones in Vietnamese

\begin{tabular}{lll} 
Eras & OC and MC Source & Corresponding Tones in ESV and LSV Layers \\
\hline $\begin{array}{ll}\text { Earliest } \\
\text { Middle }\end{array}$ & $\mathrm{OC}^{*}-\mathrm{s} /{ }^{*}-\mathrm{h}$ & $\mathrm{ESV} \rightarrow$ hỏi/ngã tones \\
& Loss of OC ${ }^{*}-\mathrm{s} /{ }^{*}$-h leading to MC & $\mathrm{ESV} \rightarrow$ hgang/huyền tones \\
Latest & qusheng tones & \\
& MC qusheng tones & LSV $\rightarrow$ sắc/nặng tones \\
\hline
\end{tabular}

secondary features appear to have the expected tones specifically according to the segmental phonemes. It is not impossible that, for example, the glottalization of pre-register split MC tones could have resulted in the sắc/nặng tones in Vietnamese, but this is difficult to demonstrate at this time. Sagart (1986:85) similarly shows how, in many modern varieties of Chinese, glottalization and breathiness are features associated with tones. The large number of ESV items which have level ngang and huyền tones suggest that any hypothetical remaining breathiness in the EMC tones did not have any impact on how they were borrowed. Regardless of the phonetic details, the overall correspondences shown in Table 4 are robustly supported.

Returning to the question of the final laryngeal phonemes, again, many qusheng tone words in ESV vocabulary have the level ngang and huyền tones, as noted in Table 4. A primary goal of this paper is to show that ESV words with ngang and huyền tones (comparable to pingsheng tones) for qusheng tone category words, represent the loss of final fricatives in OC transitioning to MC. Also, it is hypothesized that ESV words with shangsheng for qusheng words (Hỏi/Ngã-for-Qu) are older than their pingsheng counterparts as they were borrowed when final OC fricatives still existed. These eras of SV vocabulary and development of tones in the qusheng category are summarized in Table 5.

Further evidence for the process of tonogenesis in later stages of Vietic comes from the southern Vietic languages (i.e. Vietic languages other than those in the Viet-Muong ${ }^{9}$ sub-branch). While Viet-Muong

9 For this paper, the following general periods of the ancentral history of Vietnamese are assumed. The focus in this study is the later period of Vietic and the distinction of northern and southern Vietic leading to Viet-Muong.

Austroasiatic: This was prior to or in the early stages of differentiation of Austroasiatic language groups. It was nontonal and polysyllabic. It has been hypothesized that Austroasiatic dispersal through Mainland Southeast Asia occurred around 4,0oo years ago (Sidwell and Blench 2011, Higham 2017).

Vietic: This stage began after differentiation from other Austroasiatic language groups (no data is available to provide an approximate period). The group was presumably fully distinct by the time of contact with Sinitic as some Chinese loanwords are reconstructable in Proto-Vietic. There was gradual north-south differentiation during heavier language contact with Sinitic in the northern part. Vietic was polysyllabic, with likely iambic stress and sesquisyllabicity (cf. Ferlus 2004), and it may have had phonation, but tones are not reconstructable as not all Vietic languages have tones.

Viet-Muong: This northern Vietic language group developed after several centuries of significant language contact with Sinitic (no specific time can be offered here), differentiating it from southern Vietic. It may have had presyllables (though how much reduction from the early stages is uncertain), and it had a fully developed tone system.

Vietnamese: After distinction from Muong languages early in the 2nd millennium CE and seen in Chinese-based Nôm texts representing the Vietnamese language, Vietnamese passed through ancient to modern stages (such stages have not yet been precisely identified), with gradual emergence of northern, central, and southern regional varieties. Early textual data shows lingering remnants of presyllables in the first few centuries of the 2nd millennium CE (Masaaki 2015), but only initial clusters remained until the 19th century (Vu 2019). 
languages have full tone systems (i.e. at least three main categories), the other Vietic languages have a mix of situations ranging from two main tone categories to only systems of phonation/registral features. The Chứt languages (e.g. Rục (Nguyễn V. L. 1993) and Mày (Babaev and Samarina 2018)) have four-tone systems: two main categories split by register/height. Perceiving them through the MC tone system, they have tones corresponding to Vietnamese ngang and huyền tones (i.e. level tones) and to sắc and nặng tones (i.e. contour tones), but not tones corresponding to hỏi and ngã tones in Vietnamese. This is due to retention of final $/ \mathrm{h} /$ in those languages, which essentially reduces by one the number of tone categories. In contrast, some Vietic languages to the southwest of northern Vietnam do not have contour tones but rather register systems and retention of final $/ \mathrm{h} /$ and sometimes $/ \mathrm{s} /$, such as Thavung with a four-way register system involving breathiness and creakiness (Premsrirat 1996). The Kri language similarly lacks a tone system but rather has a system involving what Enfield and Diffloth (2009) describe as register ('heavy' versus 'light' syllables) plus 'terminance' (voiced, voiceless, and checked). Ferlus (1998) reviews many of the types of tone and/or register systems of the language group.

These are all suggestive of the characteristics of Vietic phonology in the period of contact with Sinitic and stages of evolution of tones in Viet-Muong. The lack of tones in some but presence of at least phonation in most (if not all, though this is an unanswered question) suggests proto-Vietic lacked tone but had phonation features (cf. Diffloth 1989). It also demonstrates a hypothetical situation in which Vietnamese, and other Vietic languages, could have followed a path of tonogenesis independently of Sinitic with the retention of final *-h, leading to these smaller sets of tones. Overall, while language contact with Sinitic appears to have affected the ultimate development of the tone system of Vietnamese, it was not a case of borrowing Chinese tones. This idea will be revisited in Sections 2.2 and 2.6.

\subsection{Sinitic-Vietic Contact History}

Historical records suggest that initial contact between Sinitic-speaking peoples and those of modern-day northern Vietnam occurred at least during the western Han Dynasty from 111 BCE, the beginning of Han administrative control, if not earlier. However, more intense sociocultural contact, for the time when there is both historical textual evidence and archaeological evidence of a substantive Chinese population in modern-day northern Vietnam, begins in the eastern Han in the first century CE (e.g. Taylor 2013:50-52, Alves 2016). Thus, the first few centuries CE were the probable beginning of substantive lexical borrowing. It is now reasonably widely accepted that, at the time of initial Sinitic-Vietic language contact around 2,00o years ago, neither Sinitic nor Vietic were tonal. The four primary tone categories in Chinese (ping, shang, qu, and $r u$ ) were used in the Chinese rhyming dictionary, the Qieyun, in 601 CE, and these tone categories were even mentioned in texts a century earlier (Baxter 1992:304), giving an approximate timing of their emergence. These four categories have been maintained with substantial regularity in all contact language groups in the Sinosphere, including Vietic, Tai ${ }^{10}$ and Hmong-Mien, ${ }^{11}$ as shown in Table 6. OC reconstructions and MC transcriptions are those of Baxter and Sagart (2014).

In an overview of five possible scenarios of the sequence of tonogenesis among Sinitic, Vietic, Kradai, and Hmong-Mien, Ratliff (2010:184-192) has hypothesized that rather than Sinitic being a fully tonal language bringing tones to the south, tonogenesis in those languages most likely occurred in a similar period after the movement of Sinitic southward. Support for this claim is that early Chinese loanwords in the

\footnotetext{
10 Key works on the history of tones of Proto-Tai include those of Li 1977 and Pittayaporn 2009, and for Proto-Hlai, see Norquest 2010. To this author's knowledge, there is no reconstruction of tones for proto-Kradai. 
TABLE 6 Patterns of Tonal Correspondences in the Sinosphere

\begin{tabular}{|c|c|c|c|c|}
\hline Tones & A & B & C & D \\
\hline Character & $\begin{array}{l}\text { 正 zhēng 'ist } \\
\text { month' }\end{array}$ & 染 răn 'to dye' & $\begin{array}{l}\text { 箸 zhù } \\
\text { 'chopsticks' }\end{array}$ & 狹 xiá 'narrow' \\
\hline $\begin{array}{l}\text { Old Chinese (Baxter } \\
\text { \& Sagart 2014) }\end{array}$ & ${ }^{*}$ C.ten & ${ }^{*} \mathrm{C} . \mathrm{n}[\mathrm{a}] \mathrm{m} ?$ & ${ }^{*}[\mathrm{~d}]<\mathrm{r}>$ ak-s & ${ }^{*} \mathrm{~N}-\mathrm{k}^{\mathrm{S}} \mathrm{rep}$ \\
\hline $\begin{array}{l}\text { Hmong-Mien (Ratliff } \\
\text { 2010) }\end{array}$ & $\begin{array}{l}\text { *sjey 'first day of } \\
\text { month' }\end{array}$ & $\begin{array}{l}\text { *num }{ }^{\mathrm{C}} \\
\text { (Mienic only) }\end{array}$ & ${ }^{*} \mathrm{drou}^{\mathrm{H}}$ & $\begin{array}{l}{ }^{*} \mathrm{hep}^{\mathrm{D}} \\
\text { (Mienic only) }\end{array}$ \\
\hline $\begin{array}{l}\text { Tai (Pittayaporn 2009) } \\
\text { Vietnamese }\end{array}$ & $\begin{array}{l}\text { *ciə̄ } \\
\text { giêng (SV chinh) }\end{array}$ & $\begin{array}{l}\text { *nwu:mc } \\
\text { nhuộm (SV nhiễ m) }\end{array}$ & $\begin{array}{l}\text { *thü }{ }^{\mathrm{B}}(\mathrm{Li} 1977) \\
\text { đũa (SV trợ })\end{array}$ & $\begin{array}{l}\text { * gap }{ }^{\mathrm{D}} \\
\text { hẹp (SV hiệp) }\end{array}$ \\
\hline
\end{tabular}

TABLE 7 Chronology of Sinitic and Vietic Language Contact and Stages of Tonogenesis

\begin{tabular}{|c|c|c|c|}
\hline Era & Contact Situation & Sinitic & Vietic \\
\hline o CE (Han Dynasty) & Early Sinitic-Vietic contact & LOC: nontonal & Vietic: nontonal \\
\hline 601 CE (Sui Dynasty) & Developed Sinitic-Vietic contact & EMC: tonal & Vietic: no n tonal \\
\hline $\begin{array}{l}1000 \text { CE (Vietnamese } \\
\text { independence) }\end{array}$ & $\begin{array}{l}\text { Chinese in northern Vietnam in } \\
\text { process of shifting to Viet- Muong }\end{array}$ & LMC: tonal & Viet-Muong: tonal \\
\hline
\end{tabular}

other language groups in the region which retained the Chinese tone categories, including non-level contour tones, must have been borrowed with original segmental features (but also likely phonation features related to those segments), not tones. Non-tonal languages do not have the phonological system by which tones can be borrowed, and thus the phonological consistency means that such borrowing happened prior to tonogenesis and when Sinitic still had final glottal stop and final fricatives.

Table 7 summarizes these implications. At the beginning of the Common Era, neither Sinitic nor Vietic had tones. Before tonogenesis in OC, Vietic speakers were able to perceive final glottal stop and fricatives; otherwise, the tonal correspondences would not have been as regular. By the 6oos, Sinitic/ Chinese had four tone categories, while Vietic was still nontonal, and thus unable to borrow tones of words. This detail pushes Haudricourt's (1954b:81) speculation of the 6th century tonogenesis in the ancestral language of Vietnamese at least a couple of centuries later.

\subsection{From ESV to LSV Vocabulary}

An important source of comparative data to study Chinese tonogenesis is Chinese loanwords in Vietnamese, which include doublets (and even triplets as shown in Table 17 of Section 6.2). One probable hypothesis is that the path of tonogenesis in Vietic was influenced by language contact with Sinitic after Sinitic developed tones, and ESV data shows that Vietic speakers borrowed Sinitic words with their final laryngeals and fricatives. However, as has been noted (Pulleyblank 1962, Zhu 2009), the timing of the loss of final fricatives likely took place prior to the loss of Sinitic's final glottal stop. Pulleyblank (1962:217-220) used textual data regarding transcriptions of foreign words in Buddhist transcriptions to demonstrate that final fricatives existed in Chinese through the 3 rd and into the 4 th century CE. Zhu $(2007,2015)$ has 
TABLE 8 Stages of ESV to LSV with respect to segments, tones, production, and perception

Stage one Vietic speakers borrowed OC words with ${ }^{*}$-s $/{ }^{*}$-h and ${ }^{*}-2$; there were no tones to perceive in OC.

Stage two Vietic speakers borrowed EMC words with *-?; tones could not be perceived as phonological elements.

Stage three Viet-Muong speakers borrowed MC words with tones; Viet-Muong had tones and could perceive and adopt tones.

hypothesized that the final glottal stop (though Zhu suggests the final glottal was a possibly secondary feature) lasted until the 7 th century.

What the comparative data in this study suggests is three stages of loanword strata in Vietnamese reflecting three periods of the development of the Sinitic tone system, summarized in Table 8. The factors involve available segments and tones in terms of both production by Sinitic speakers and perception by Vietic speakers. In the third stage, all final laryngeals had been lost, Vietic had become tonal, and the combined Sinitically-influenced Vietic and the MC speech community created circumstances to allow consistent borrowing of MC tones. This accounts for the changing patterns of tones between ESV and Lsv listed in Table 4.

Eras and Phonological Traits of Sinitic Loanwords in Vietic

Before exploring the issues of source words and tones of ESV vocabulary, characteristics of ESV vocabulary and phonemes are summarized in this section. The earliest major study of the historical phonology of SV vocabulary is that of Maspero (1912), but early significant studies of different strata of Chinese words in Vietnamese are those of Wang (1948 and 1958) and Haudricourt (1954a). Vietnamese scholars have also explored other layers of SV (Đào 1979, Nguyễn T. C. 1995, Vương 2002, Nguyễn N. S. 2003, Nguyễn T. T. 2015). Other researchers have also explored early layers of SV (Mei 1970, Tryon 1979, Pulleyblank 1981 and 1984, Schneider 1992, Baxter and Sagart 2014, Phan 2013, Alves 2016, Jia (unpublished notes), etc.). The ESV lexical data provided in this study come from these sources and other ESV words I have identified.

The term 'Sino-Vietnamese' may refer to formally recognized (e.g. listed in dictionaries) Vietnamese pronunciations of Chinese characters, what have been referred to in this study as LSV, the later, literary layer of SV. More broadly, SV vocabulary is associated with MC, which could stem from the second half of the ist millennium and before Vietnamese independence from China, while LSV is associated with LMC of the early second millennium, after administrative independence. These character readings include the entirety of the Chinese character inventory. Some of these LSV words have become part of spoken Vietnamese, while some have remained part of the literary tradition with little or no usage in spoken Vietnamese. This is similarly the case in Sino-Korean and Sino-Japanese. However, unlike the non-tonal Sino-Korean and Sino- Japanese readings, LSV has retained the tone categories listed in Chinese dictionaries, such as the Guangyun, and therefore represent a practice involving literacy but also a period of extensive Sinitic-Vietic bilingualism to allow for the consistent borrowing of tones in spoken Vietnamese. Phan (2013) has hypothesized what he calls Annamese Chinese, essentially a variety of MC in northern Vietnam in the first century millennium that was eventually lost, most likely due to language drift and merging with Viet-Muong. Such a situation accordingly left a substantial amount of lexical borrowing, which is still being uncovered as methods of identifying them (both linguistic and extralinguistic data and the use of lexical databases) have grown. 
However, prior to that period of adoption of Chinese phonology through both literary and spoken transmission, many Chinese words were borrowed solely through speech, not through a literary tradition. This requires only that two languages be spoken in a community, without text as a necessary source for borrowing, though there were signs of literacy among the population in the region, such as locals participating in the civil service exams (e.g. Taylor 1983:219-220). Correspondingly, ESV words are well integrated in spoken Vietnamese, and there is a much smaller number of these words than the total number of Chinese characters. The identification of ESV items has been challenging as they are different from their LSV counterparts phonetically and sometimes semantically as well, whether due to changes in Sinitic, Vietic, or both. ESV borrowings extend from the periods of LOC to EMC, and likely into MC proper before tonogenesis in the Viet-Muong sub-branch of Vietic. The various characteristics of LSV and ESV vocabulary are summarized in Table 9.

The result is that there are hundreds of Chinese doublets involving the ESV and LSV layers (though as will be shown, some words were borrowed twice in the ESV period, resulting in triplets). The phonological differences can be seen in initials, vowels, and finals. In Table 10, ESV items retain OC *r, as in 'dragon' and 'bamboo curtain', while LSv items match the change to MC *l. According to available data, OC items with presyllables and either bilabial initials (e.g. 'square' and 'wall') and medial *-w- (e.g. 'to draw/paint') have lenited to initial /v/ in ESV items (with similar patterns in Vietnamese words in general, as described by Ferlus (1982)), while again, the LSV and MC initials match. As for vowels, one common phenomenon is diphthongization, as in 'square', 'stele', and 'must'. OC *e is often retained in ESv items without the TABLE 9 Features of LSV and ESV Vocabulary

\begin{tabular}{|c|c|c|}
\hline Aspects & ESV & LSV \\
\hline Era & - From LOC to EMC and MC proper & - Largely from LMC \\
\hline Relation to & - Borrowed prior to tonogenesis in Vietic & - Borrowed after tonogenesis in Viet-Muong \\
\hline tones & $\begin{array}{l}\text { - Patterns of tone categories differing } \\
\text { in various ways from those of MC } \\
\text { and LSV proper }\end{array}$ & $\begin{array}{l}\text { - Retained all MC tone categories with high } \\
\text { consistency }\end{array}$ \\
\hline Usage & $\begin{array}{l}\text { - Either not recognized as Chinese in } \\
\text { origin or not considered standard } \\
\text { readings of Chinese characters } \\
\text { - } \text { Highly integrated (i.e. typically part } \\
\text { of vernacular Vietnamese, perceived } \\
\text { as native/non-Chinese, etc.) }\end{array}$ & $\begin{array}{l}\text { - Vietnamese phonology for readings of all } \\
\text { Chinese characters } \\
\text { - Part of the East Asian and Sino- Xenic liter- } \\
\text { ary tradition }\end{array}$ \\
\hline $\begin{array}{l}\text { Means of } \\
\text { transmission }\end{array}$ & $\begin{array}{l}\text { - Borrowings primarily via spoken } \\
\text { Sinitic-Vietic bilingualism }\end{array}$ & $\begin{array}{l}\text { - Indication of both Sinitic-Vietic wide- } \\
\text { spread bilingualism and a literate Sino- } \\
\text { Viet elite } \\
\text { - Associated with the loss of Annamese- } \\
\text { Chinese due to language shift with Viet- } \\
\text { Muong and cultural merging with Viet- } \\
\text { Muong groups }\end{array}$ \\
\hline Quantity & $\begin{array}{l}\text { - Not as large numerically as } \\
\text { Chinese characters, currently several hundred } \\
\text { items of medium to high certainty }\end{array}$ & $\begin{array}{l}\text { - Constituting all Chinese characters, with } \\
\text { thousands in spoken Vietnamese }\end{array}$ \\
\hline
\end{tabular}




\begin{tabular}{|c|c|c|c|c|c|}
\hline GLOSS & CHIN & $\mathrm{OC}$ & MC & ESV & LSV \\
\hline dragon & 龍 lóng & *[mə]-roy & ljowng & rồng & long \\
\hline bamboo curtain & 簾 lián & *rem & ljem & rèm & liêm \\
\hline square & 方 fāng & ${ }^{*} \mathrm{C}-$ pay & pjang & vuông & phương \\
\hline wall & 壁 bì & ${ }^{*} \mathrm{C} . \mathrm{p}^{\mathrm{S}} \mathrm{ek}$ & pek & vách & bích \\
\hline draw/paint, to & 劃 huà & ${ }^{*} \mathrm{C}-\mathrm{g}^{\mathrm{wS}}$ rek-s & hweaH & vẽ & họa \\
\hline new year & 節 jiē & ${ }^{*} \mathrm{ts}^{\mathrm{S}_{\mathrm{i}} \mathrm{k}}$ & tset & tết & tiết \\
\hline side & 邊 biān & ${ }^{*} \mathrm{p}^{\mathrm{S}} \mathrm{e}[\mathrm{n}]$ & pen & bên & biên \\
\hline father's elder brother & 伯 bó & ${ }^{*} \mathrm{p}^{\mathrm{q}} \mathrm{rak}$ & paek & bác & bách; bá \\
\hline white/silver & 白 bái & ${ }^{*} b^{\text {S }}$ rak & baek & bạc & bạch \\
\hline level (adj.) & 平 píng & *m-brey & bjaeng & bằng & bình \\
\hline stele & 碑 bēi & *pre & pje & bia & bi \\
\hline must & 須 $x \bar{u}$ & $*[\mathrm{~s}] \mathrm{o}$ & sju & tua & tu \\
\hline
\end{tabular}

TABLE 11 General Patterns of Segmental Correspondences between ESV and LOC/EMC

\section{Consonants}

- Retention of single-consonant initials and finals (nasals, stops, liquids)

- Loss of LOC/EMC medials (e.g. *-r-, ${ }^{*}$-j-, etc.) in initial clusters

- Development of initial fricatives (e.g. $/ \mathrm{v} /, / \gamma /$, etc.) from presyllabic material in LOC

Vowels

- Retention of OC/MC vowels (e.g. *e, *a, *o, etc.)

- Diphthongization of single vowels in LOC (?) loans (e.g. /iə/, /uə/, /iə/)

palatal medial, as in 'bamboo curtain' and 'side'. In ESv, final velars of OC are retained instead of the palatalized finals of LSV, as in 'white/silver' and 'level (adj.)'. Many other instances of such patterns are seen in available data.

Table 11 provides an overview of the kinds of phonological characteristics of ESV vocabulary. These patterns, among others, underlie the ESV items throughout this paper in assessing the degree of certainty of posited ESV vocabulary. Publications noted above should be considered for more clarification. More work is needed in this aspect, and this paper cannot account for all the segmental patterns.

In addition to ESV words with segmental differences from their LSV counterparts, some ESV items differ from LSV only in tone, for example, ESv cám 'thanks' versus LSV cảm (from Chinese 感 găn 'thanks') and ESv dùng 'to use' versus LSv dụng (from Chinese 用 yòng 'to use'). Dozens of such words are presented in this paper, data which can be explained by assuming previous segmental features in LOC and EMC, and their loss can also be evidenced in ESV data, primarily via tones. While this section has dealt with segmental features of ESV, subsequent sections focus on suprasegmental features. 
The observation of the alternation between ESV and LSV words in the Chinese shangsheng/rising and qusheng/departing tone categories was important half a century ago in understanding the segmental/ consonantal features of the words that developed those tone categories in MC (Mei 1970). Sagart (1988) further clarified the pattern, putting in a larger context the region of Sinitic, Vietic, Tai, and Hmong-Mien. Further support for the posited loanwords showing the hỏi/ngã and sắc/năng reversal (in a sense, a reversal of the shangsheng and qusheng categories) between ESV and LSV items in the early first millennium $\mathrm{CE}$ has been given from extralinguistic sources, such as textual and archaeological data (Alves 2016). Moreover, in the vast majority of cases identified for this paper, the tone height is consistent: ESV items with upper register tones most often ${ }^{12}$ also have upper register tones in their LSV counterparts, and the same is the case for words with lower register tones. Thus, combined with consistency of segmental and semantic features and, in many cases, culturally specific items, actions, and concepts, the certainty of proposed ESV items as earlier loanwords than LSV vocabulary is medium to high in the data presented in this study.

As described in Section 3, many ESV items having tones contrasting with the later LSv layer have other segmental differences that further identify them as early borrowings. For ESV words with sắc/năng tones, while their LSV counterparts have hỏi/ngã tones, that is, when OC still retained final glottal stops, a substantial majority of the items have segmental differences from their LSV MC-era counterparts ( 78 differing, but only 15 the same). The ESV words with hỏi/ngã tones versus LSV sắc/năng tone words primarily consist of groups of words with segmental differences from the later MC-era loans, but with a slightly higher relative quantity of those with the same segments (31 differing, but 4 the same). These numbers are summarized in Table 12, which also lists the tables in the Appendix with the relevant categories of ESV items. Table 13 contains samples from the full tables in the Appendix. Additional labels of A, B, C, and $\mathrm{D}$ for the four tone categories and 1 and 2 for high and low register (e.g. B1 for $\mathrm{C} 1$ ) are shown to further clarify the tone categories.

TABLE 12 ESv Hỏi/Ngã Words versus LSv Sắc/Nặng Words (B versus C) and ESv Sắc/Nặng words versus LSv Hỏi/Ngã Words (C versus B)

\begin{tabular}{llll}
\hline ESV to LSV Tone Correspondences & $\begin{array}{l}\text { Similarity to } \\
\text { segments in LSV }\end{array}$ & Quantity & $\begin{array}{l}\text { Tables in } \\
\text { Appendix }\end{array}$ \\
\hline Hỏi versus Sắc tone words (B1 vs. C1) & differing & 16 items & $\mathrm{A}$ \\
Ngã versus Nặng tone words (B2 vs. C2) & differing & 15 items & $\mathrm{B}$ \\
Ngã versus Nặng tone words (B2 vs. C2) & the same & 4 items & $\mathrm{C}$ \\
Sắc versus Hỏi tone words (C1 vs. B1) & differing & 46 items & $\mathrm{D}$ \\
Sắc versus Hỏi tone words (C1 vs. B1) & the same & 13 items & $\mathrm{E}$ \\
Nặng versus $N g \tilde{a}$ tone words (C2 vs. B2) & differing & 32 items & $\mathrm{F}$ \\
Nặng versus $N g \tilde{a}$ tone words (C2 vs. B2) & the same & 2 items & $\mathrm{G}$ \\
& TOTAL & 128 items & \\
\hline
\end{tabular}

12 There are a small number of exceptions, alternations in register, which are not explainable at this time. These instances may represent the effect of presyllabic material, whether from OC or even possibly the addition of affixes in Vietic. 
TABLE 13 Samples of ESV versus LSV items - Sắc/Nặng versus Hỏi/Ngã and Hỏi/Ngã versus Sắc/Nặng

\begin{tabular}{|c|c|c|c|c|c|}
\hline GLOSS & CHIN & OC & MC & ESV & LSV \\
\hline \multicolumn{6}{|c|}{ A. hỏi versus sắc (B1 vs. $\mathrm{C} 1$ ) - differing segments } \\
\hline to marry & 嫁 jià & ${ }^{*} \mathrm{~s} . \mathrm{k}^{\mathrm{S}} \mathrm{ra}-\mathrm{s}$ & $\mathrm{kaeH}$ & gả & giá \\
\hline age & 歲 suì & ${ }^{*} \mathrm{~s}-\mathrm{q}^{\mathrm{wh}}$ at-s & sjwejH & tuổi & tuế \\
\hline measure for divinations & 卦 guà & ${ }^{*}[\mathrm{k}]^{\mathrm{wS}} \mathrm{re}-\mathrm{s}$ & kweaH & quẻ & quái \\
\hline \multicolumn{6}{|c|}{ 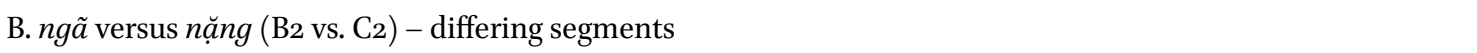 } \\
\hline word (in writing) & 字 zì & ${ }^{*} \mathrm{~m} \partial-\mathrm{dz} \partial-\mathrm{s}$ & dziH & chũ & tự \\
\hline chopsticks & 箸 zhù & $* \mathrm{~d}<\mathrm{r}>$ ak-s & drjoH & đũa & trợ \\
\hline hat & 帽 mào & ${ }^{*} \mathrm{~m}^{\mathrm{S}} \mathrm{uk}-\mathrm{s}$ & mawH & mũ & mạo \\
\hline \multicolumn{6}{|c|}{ C. $n g a \tilde{a}$ versus nặng (B2 vs. C2) - the same segments } \\
\hline two & 二 èr & *ni[j]-s & nyijH & nhĩ & nhị \\
\hline think & 議 yì & ${ }^{*} \mathrm{y}(\mathrm{r}) \mathrm{aj}-\mathrm{s}$ & ngjeH & nghĩ & nghị \\
\hline \multicolumn{6}{|c|}{ D. Sắc versus hỏi (C1 vs. B1) - differing segments } \\
\hline noodles & 粉 fěn & *mə.pən? & pjunX & bún & phấn ${ }^{13}$ \\
\hline lord & 主 zhǔ & $*$ to? & tsyuX & chúa & chủ \\
\hline paper & 紙 zhǐ & ${ }^{*} k . t e ?$ & tsyeX & giấy & chỉ \\
\hline \multicolumn{6}{|c|}{ E. Sắc versus hỏi $\left(\mathrm{C}_{1}\right.$ vs. $\left.\mathrm{B} 1\right)$ - the same segments } \\
\hline light, glare & 影 yǐng & *qrap? & jaengX & ánh & ảnh \\
\hline rather, very & 可 kě & ${ }^{*}[\mathrm{k}] \mathrm{hS} \mathrm{a}[\mathrm{j}] \mathrm{P}$ & khaX & khá & khả \\
\hline to order/bid & 遣 qiăn & ${ }^{*}[\mathrm{k}]^{\mathrm{h}} \mathrm{e}[\mathrm{n}] \mathrm{P}$ & khjienX & khiến & khiển \\
\hline \multicolumn{6}{|c|}{ F. $n a ̆ g n g$ versus $n g \tilde{a}$ (C2 vs. $\mathrm{B} 2)$ - differing segments } \\
\hline father's younger brother & 舅 jiù & $*[\mathrm{~g}](\mathrm{r}) \mathrm{u} ?$ & gjuwX & cậu & cữu \\
\hline net & 網 wăng & *maj? & mjangX & mạng & võng \\
\hline to wait & 待 dài & $*[\mathrm{~d}]^{\mathrm{c} \partial ?}$ & $\operatorname{dojX}$ & đợi & đãi \\
\hline \multicolumn{6}{|c|}{ G. nănng versus ngã (C2 vs. B2) - the same segments } \\
\hline to receive, acknowledge & *rěn & ${ }^{*} \mathrm{n} \partial[\mathrm{n}] ?$ & nyinX & nhận & nhẫn \\
\hline cold & 冷 lěng & NONE & NONE & lạnh & lãnh \\
\hline
\end{tabular}

While the data in this study undoubtedly does not include all possible ESv items, and more will likely be identified, the numbers of items in each category are already telling. While only 34 instances of the $\mathrm{C}$-for-B type are in the data herein, there are at least 90 items of B-for-C type. The semantic categories of both types are varied, indicating no significant difference in sociolinguistic circumstances of borrowing. The significantly larger number of sắc/nặng-for- hỏi/ngã words makes sense considering the longer period during which the OC/EMC glottal stop may have lasted, than did the final fricatives, which were

13 The expected tone in this LSV word is the hỏi tone. The actual sắc tone may reflect a pronunciation retained from the pre-tonal period of Vietnamese, and thus it may also be a kind of ESV that became standard reading of the character 粉 fěn. 
lost in OC a few centuries sooner. Moreover, among the ESV items, about 135 differ segmentally from their LSV counterparts, while only about $5^{0}$ have the same segments. As will be shown in the next section, nearly half of those 50 are words with ngang/huyền tones in qusheng words. Assuming that ESV words with segments differing from the LSv layer are typically older than those with the same segments, a substantial percentage was borrowed in an earlier period, though details are sketchy at this point. Having provided such data, we can now review data of the instances of $n g a n g /$ huyền tones in qusheng words.

\section{Lexical Data for the Ngang/Huyền Tones in Qusheng Words}

As described in Section 1, in available ESv data, a large number of items have level ngang/huyền tones (corresponding to MC pingsheng tones) in early Chinese loanwords which are words formally listed as having qusheng category tones, sắc and nạng tones, as they are in LSV words. The loss of OC *-s around the 3 rd century CE was hypothesized by Pulleyblank 1962, and it is thus reasonable to consider this loss as a viable source of this otherwise unexpected tonal phenomenon in ESV vocabulary. That is, the loss of final fricatives in OC meant that Vietic speakers, whose phonological system lacked tones, could have only borrowed the segments of the words, which later resulted in level ngang and huyền tones in Vietnamese.

Like the alternation between shangsheng and qusheng between ESV and LSV strata, some of the ESV items with level ngang/huyền (pingsheng) tones for what are considered qusheng words also have segmental differences, but in a comparable number of instances, they do not. Also, unlike the alternation between ESV and LSV of shangsheng and qusheng categories, the pattern for the ngang/huyền tones in qusheng tone category words is one-sided: there are only ngang/huyền items in qusheng words, not sắc/ nặng tones in pingsheng tone category words, which is expected as words with pingsheng tones are not conditioned by finals. ${ }^{14}$ Again, the consistency in tone height/register between the ESV and LSV counterparts strengthens the assertion that these are not the result of chance or irregularities due to random lexical borrowing. Table 14 shows four situations based on the two-tone register/heights and the segmental similarity to related MC forms. A majority of the ESV items have the same segments as in LSV, which highlights the relatively later historical starting point of this category compared to the shangsheng/qusheng phenomenon discussed in Section 4. Samples of all four categories are provided in Table 15.

Assuming ESV items with ngang/huyền tones in qusheng words are the result of borrowing Sinitic words after the complete loss of final fricatives, these words must have been borrowed from perhaps the early to mid-first millennium CE until the time Viet-Muong developed tones some centuries later. The relatively larger quantity of ESV items with the same segments as MC-era LSV words attests to this later time of borrowing of these items. Considering Table 1 in the first section, it appears that the amount of functional vocabulary was on the increase in the second half of the first millennium CE, an issue that

14 There are some instances, such as mối 'matchmaker' (SV môi, Chinese 媒 méi), nghiến 'to grind (SV nghiên, Chinese 研), among other instances which do appear reasonable candidates as Chinese loanwords despite the seeming tonal oddity (i.e. $q u$-for-ping). However, these are very small in number, and there is no apparent phonological source for qusheng tones on pingsheng words as the latter did not have final segments to influence the development of tone contour. It remains to be seen what other factors could have resulted in these forms (e.g. changes in the tone system of Viet-Muong, tonal morphology, irregular borrowing circumstances, etc.). 
TABLE 14 ESv Ngang/Huyền Words versus LSv Sắc/Nặng Words (Category A vs. C)

\begin{tabular}{llll}
\hline ESv to Lsv Tone Correspondences & Similarity to Segments in LSv & Quantity & Table \\
\hline Ngang versus Sác (A1 vs. C1) & differing & 17 & $\mathrm{H}$ \\
Ngang versus Sác (A1 vs. C1) & the same & 15 & $\mathrm{I}$ \\
Huyền versus Nặng (A2 vs. C2) & differing & 19 & $\mathrm{~J}$ \\
Huyền versus Nặng (A2 vs. C2) & the same & 22 & $\mathrm{~K}$
\end{tabular}

TABLE 15 Examples of Correspondences of ESv Ngang/Huyền versus LSv Sắc/Nặng Tones (Category A vs. C)

\begin{tabular}{|c|c|c|c|c|c|}
\hline GLOSS & CHIN & $\mathrm{OC}$ & MC & ESV & SV \\
\hline \multicolumn{6}{|c|}{ H. Ngang versus Sắc (A1 vs. C1) - differing segments } \\
\hline saw (n.) & 鋸 jù & ${ }^{*} \mathrm{k}(\mathrm{r}) \mathrm{a}-\mathrm{s}$ & $\mathrm{kjoH}$ & cưa & cứ \\
\hline to shout/call & 叫 jiào & ${ }^{*} \mathrm{k}^{\mathrm{S}}$ ewk-s & kewH & kêu & khiếu \\
\hline to temper (of steel) & 焠 cùi & $*\left[\mathrm{ts}^{\mathrm{h}}\right]^{\mathrm{s}} \mathrm{u}[\mathrm{t}]-\mathrm{s}$ & tshwojH & tôi & thối \\
\hline \multicolumn{6}{|c|}{ I. Ngang versus Sắc (A1 vs. C1) - the same segments } \\
\hline $\operatorname{belt}(n)$. & 帶 dài & ${ }^{*} \mathrm{C} . \mathrm{t}^{\mathrm{S}} \mathrm{a}[\mathrm{t}]-\mathrm{s}$ & tajH & đai & đái \\
\hline to encourage; advise & 勸 quàn & ${ }^{*}$ C.q ${ }^{\text {wh }}$ ar-s & khjwonH & khuyên & khuyến \\
\hline report to king & 奏 zòu & ${ }^{*} \operatorname{ts}^{\mathrm{S}} \mathrm{O}(\mathrm{P})-\mathrm{s}$ & tsuwH & tâu & tấu \\
\hline \multicolumn{6}{|c|}{ J. Huyền versus Nặng (A2 vs. C2) - differing segments } \\
\hline then & 便 biàn & *ben-s & bjienH & bèn & tiện \\
\hline to wait for, desire & 望 wàng & *may-s & mjang & mòng & vọng \\
\hline to smelt/forge & 鍊 liàn & $*[r]^{\mathrm{S}} \mathrm{en}-\mathrm{s}$ & lenH & rèn & luyện \\
\hline \multicolumn{6}{|c|}{ K. Huyền versus Nặng (A2 vs. C2) - the same segments } \\
\hline curtain; screen & 幔 màn & ${ }^{*} \mathrm{~m}^{\mathrm{S}} \mathrm{a}[\mathrm{n}]-\mathrm{s}$ & $\operatorname{manH}$ & màn & mạn \\
\hline sentiment & 念 niàn & ${ }^{*} \mathrm{n}^{\mathrm{S}} \mathrm{im}-\mathrm{s}$ & nemH & niềm & niệm \\
\hline rhyme & 韻 yùn & $*\left[\mathrm{~m}-\mathrm{q}^{\mathrm{w}}\right]<\mathrm{r}>\mathrm{i}[\mathrm{n}]-\mathrm{s}$ & hwinH & vần & vận \\
\hline
\end{tabular}

highlights the persistent, substantial impact of the local Annamese Chinese group in northern Vietnam prior to tonogenesis in Vietic.

\section{Implications of the Data: Perception of Sounds and the Relative Chronology of Tonogenesis}

Wang (2006) asserts that OC may have had two classes of qusheng words: those with final *-s and those without it. Citing Ting's (1981) observations of SV vocabulary, Wang (2006:3-4) notes how Chinese qusheng words appear in all six tones in Vietnamese, essentially three different tone categories pingsheng, 
shangsheng, and qusheng (not including rusheng in words with final $\mathrm{p} / \mathrm{t} / \mathrm{k}$ sounds). However, the data provided in Sections 3 and 5 explains how the three tone categories, becoming six with the split of tone height, can all come from the same qusheng category. The Chinese loanword data in Vietnamese supports claims that from LOC to EMC, there was a period of the loss of final fricatives, and it supports Pulleyblank's (1962) claim that this loss was complete by the mid-first millennium.

Thus, the data suggests ways to explain multiple strata of Chinese loanwords in Vietnamese by providing relative chronologies of the words, which in turn supports the relative chronology of Chinese tones in the first several centuries of the first millennium CE. This last section further explores the role of perception by Vietic speakers of Sinitic phonology and the impact all the data has on the timing of developments in both OC/Sinitic and early Vietic.

\subsection{The Role of Perception of Sounds}

Loanword phonology depends partly on the phonological systems of speakers of both donor and recipient languages. It has also been shown how loanword phonology depends upon both grammatical and perceptual factors of the speakers borrowing words, such as the work of Yip (2006), who presented data showing how consonants are recognized more faithfully than vowels.

In the case of SV loanwords, this is especially relevant to the matter of the final fricative and laryngeal sounds in question as the perception of these consonants appears to have been fairly consistent. OC *-s/-h was perceived in earlier periods by Vietic speakers, as the ESv data with hỏi and ngã tones attest. We can thus assume that the ngang and huyền tones in ESV vocabulary was not the result of Vietic lacking final fricatives, making Vietic speakers unable to perceive them or borrow words with those sounds. At the time of borrowing those words, there simply were no final fricatives in Sinitic for Vietic speakers to perceive. Moreover, the ngang and huyền tones in ESV words reflect perception of the loss of final *-s or *-h in Chinese but the lack of tonogenesis in Vietic. Had Vietic been tonal, the tones in borrowed words would likely have different tone categories and/or have been the same tones, as they are in LSV.

One possible complication is that while both Sinitic and Vietic have been reconstructed as having final glottal stop and fricatives, there are differences in final clusters. Final nasal-plus- glottal stop clusters (e.g. ${ }^{*}-m ?$ ) are reconstructed in Proto-Vietic (and further back to Proto- Austroasiatic), while there are no final nasal-plus-fricative clusters, unlike those reconstructed in OC. However, apparently, Vietic speakers were able to able to perceive the latter clusters and borrow them with sufficient accuracy such that there is phonological consistency in most instances.

Another aspect worth noting is secondary features related to tones and the process of tonogenesis. Tones are often accompanied by phonation features (e.g. breathiness, glottalization, creakiness, etc.), and so such features were likely part of the tone system of MC. As noted, Sagart (1986:94) presents data from a variety of modern Chinese dialects in which the shangsheng and qusheng tones have glottalization and even glottal stops. Vietic also may have had phonation creakiness (Diffloth 1989), and the features of Vietnamese and process of development likely involved registral phonation features (e.g. Alves 1995, Thurgood 2002). How long such secondary phonation features remained in the variety of MC in northern Vietnam at that time, and how that affected the phonology of these loanwords in Vietic, cannot be readily ascertained at this point. Still, it appears likely that segmental phonemes were the key features, as demonstrated by the consistent patterns, and that phonation had little to no impact on the perception by Vietic speakers of Sinitic words.

Regardless, when final fricatives were lost in Sinitic and tone categories emerged, available data suggests Vietic speakers perceived the segments of those words and borrowed them with those phonemes, while contour tone phonemes, whether or not they perceived them, could not be borrowed. The level 
ngang and huyền tone in these ESv items cannot be the result of a misperception of final consonants (even when they were in final clusters) in OC and MC as Vietic speakers did, as shown, borrow these in sizeable quantity. They were also able to distinguish voicing of initial consonants, as the regularity of tone height in ESV words shows.

\subsection{The Sequence of Development of Tones in both Sinitic and Vietic and Triplet Loanwords}

According to current hypotheses, OC *-s was lost sooner than the final glottal stop. The implication of this is that, while both ESV words with höi/ngã in qusheng words and those with sắc/nặng in shangsheng words were borrowed from the earliest period, the hỏi/ngã words, those coming from OC final fricatives, were only borrowed in that earlier period of the first few centuries $\mathrm{CE}$, while the sắc/năng words continued to be borrowed until into the second half of the first millennium. Correspondingly, there is a notably larger number of sắc/nặng-for-shangsheng words than hỏi/ngã-for-qusheng words, as noted in Section 4. Lastly, words with ngang/huyền tones in qusheng words were then borrowed starting from the later period from about the first few centuries CE until Vietic developed tones and qusheng category words could be borrowed directly with tones. The timing of Vietic tonogenesis is not certain, but we can speculate that it was a couple of centuries later than tonogenesis in Chinese, but somewhat prior to the period of Late MC.

Overall, the evidence strongly supports the notion that Chinese tonogenesis preceded Vietnamese tonogenesis. This also contributes, albeit indirectly, to the idea that tone systems were not borrowed, but rather that tonogenesis followed regional typological tendencies, as per Ratliff (2010). During the centuries-long contact, there was a long-term process of changes involving phonation features, changes in syllable structure and length, and loss of segments, all part of the contact that created the conditions for tonogenesis rather than simply borrowing of a tone system.

Combining understanding of ESV segmental phonology and the periods of tonogenesis in OC, we can identify triplets and provide relative chronologies for these items, as shown in Table 17. These triplets provide evidence of the OC final fricative of the qusheng category. Those ESV items with the earlier stage tones tend to have other segmental differences, further highlighting their age. More evidence that these items are triplets borrowed in multiple eras includes semantic differences among them within a general semantic domain, as in the case of cũng 'also', cùng 'with', and LSv cộng from Chinese 共 gòng but primarily as a bound morpheme (cf. Alves 2018). The tone categories (e.g. A1, C2, etc.) are listed next to each item. The first several follow the expected pattern of B, A, and C. The last two items, 'ten thousand' and 'cage' both have segmental differences, highlighting their age, but share tone categories with the later forms.

TABLE 16 History of ESV tones compared with Chinese Tone Development

\begin{tabular}{|c|c|}
\hline Categories & Chronology \\
\hline words with hỏi/ngã tones in & Borrowed during the retention of OC final fricatives from the Han \\
\hline qusheng words & Dynasty to MC in the early part of the first millennium CE \\
\hline $\begin{array}{l}\text { words with ngang/huyền tones in qush- } \\
\text { eng words }\end{array}$ & $\begin{array}{l}\text { Borrowed from the loss of OC final fricatives in the Han to Jin period } \\
\text { to the end of the } 1^{\text {st }} \text { millennium CE }\end{array}$ \\
\hline $\begin{array}{l}\text { words with sắc/nặng tones in shangsheng } \\
\text { words }\end{array}$ & $\begin{array}{l}\text { Borrowed during the retention of } \mathrm{OC}^{*}-\mathrm{P} \text { from the Han Dynasty into } \\
\text { MC in the Tang Dynasty in the second half of the first millennium CE }\end{array}$ \\
\hline
\end{tabular}


TABLE 17 Triplets

\begin{tabular}{|c|c|c|c|c|c|c|}
\hline Gloss & Chinese & $\mathrm{OC}$ & MC & ESV - LOC/EMC & $\mathbf{E S V}-\mathbf{E M C} / \mathrm{MC}$ & SV - LMC \\
\hline grave & 墓 mù & ${ }^{*} \mathrm{C} . \mathrm{m}^{\mathrm{S}} \mathrm{ak}-\mathrm{s}$ & $\mathrm{muH}$ & mả (B1) & mồ $(\mathrm{A} 2)$ & mộ (C2) \\
\hline disorder, rebellion & 亂 luàn & $*[\mathrm{r}]^{\mathrm{s}} \mathrm{O}[\mathrm{n}]-\mathrm{s}$ & lwanH & lẫn (B2 'to confuse' & loàn $(\mathrm{A} 2)$ 'rebel' & $\begin{array}{l}\text { loạn }(\mathrm{C} 2) \\
\text { 'confusion' }\end{array}$ \\
\hline belt & 帶 dài & ${ }^{*} \mathrm{C} . \mathrm{t}^{\mathrm{S}} \mathrm{a}[\mathrm{t}]-\mathrm{s}$ & tajH & dải (B1) & đai (A1) & đái (C1) \\
\hline with/also & $\begin{array}{l}\text { 共 } \\
\text { gōng, } \\
\text { gòng }\end{array}$ & $\begin{array}{l}{ }^{*} \mathrm{~N}- \\
\mathrm{k}(\mathrm{r}) \text { oy?-s }\end{array}$ & gjowngH & cũng (B2) 'also' & cùng $(\mathrm{A} 2)$ 'with' & cộng $(\mathrm{C} 2)$ \\
\hline interest; profit & 利 lì & ${ }^{*}$ C.ri $[\mathrm{t}]-\mathrm{s}$ & lijH & lãi (B2) & lời (A2) & lợi (C2) \\
\hline two & 二 èr & ${ }^{*} \mathrm{ni}[\mathrm{j}]-\mathrm{s}$ & nyijH & nhĩ (B2) & nhì (A2) ('second') & nhị (C2) \\
\hline ten thousand & 萬 wàn & ${ }^{*}$ C.ma $[n]-s$ & mjonH & muôn (A1) & vàn $(\mathrm{A} 2)$ & vạn (C2) \\
\hline \multirow[t]{2}{*}{ cage, coop } & 籠 lóng, & ${ }^{*} \mathrm{k} . \mathrm{r}^{\mathrm{S}} \mathrm{o \eta}$ & luwng & chuồng (A2) & lồng (A2) & $\operatorname{lung}(\mathrm{A} \mathbf{1})$ \\
\hline & lǒng & ${ }^{*} \mathrm{k} . \mathrm{r}^{\mathrm{s}} \mathrm{o \eta}$ ? & luwngX & & & lộng (C2) \\
\hline hit, kick & 打 dǎ & NONE & NONE & đánh $(\mathrm{C} 1)$ 'to hit' & đá $(\mathrm{C} 1)$ 'to kick' & đả (B1) \\
\hline
\end{tabular}

SV lexical data has offered insight into Chinese historical phonology, particularly with respect to tones, and this is again the case in the loss of final OC fricatives as seen by tonal phenomena among SV strata. Some concluding thoughts are presented below.

- Chronology: The ESV and LSV data presented supports a chronology measured broadly in centuries, but still with enough precision to allow other sociohistorical studies of, for example, cultural domains in the Sinitic-Vietic contact. The number of words borrowed in each category corresponds to length of time, which offers supporting evidence for the timing of changes in both Sinitic and Vietic. The larger number of words with sắc/nặng tones in shangsheng words than words with hỏi/ngã in qusheng words is expected considering the several centuries during which the former could have been borrowed, but only a few centuries for the latter, though all were borrowed prior to tonogenesis in Viet-Muong.

- Sinitic speech community: A review of reconstructions of Proto-Tai (e.g. Li 1977 and Pittayaporn 2009) and Proto-Hmong-Mien (Ratliff 2010) shows that while a good number of words are shared by the speech communities, many if not most ESV words are not seen in the other language groups. Thus, these are loanwords directly borrowed from Sinitic rather than, for example, indirectly via Tai. Instead, the notable number of items supports the hypothesis of a large, sociolinguistically influential Sinitic speech community. Considering the geographically peripheral and somewhat isolated status of Jiaozhi (the part of northern Vietnam under Chinese administration for a thousand-year period), it is not unreasonable to assume that the variety of Chinese spoken in northern Vietnam, so-called Annamese Chinese, experienced tonogenesis in a somewhat different way and at a somewhat different timing than Sinitic in other parts further north.

- Shared patterns of segmental loss: The data provides an example of shared tendencies in loss of classes of sounds: loss of fricatives and glottal stop (laryngeals), as well as liquids (e.g. *r and *l), but retention of other stops (i.e. $\mathrm{p} / \mathrm{t} / \mathrm{k}$ ) and nasals (i.e. $\mathrm{m} / \mathrm{n} / \mathrm{n}$ ). Such is the case in both Sinitic and VietMuong languages (though as noted, in various conservative southern Vietic languages, final /-h/ and /-1/ are retained), as well as in Tai and some Mienic languages. 
One question that remains is how many of the ESV items with the same segments as LSV words are from the earlier period, perhaps before Sinitic fully developed tones, and how many were borrowed much later but still somewhat before Vietic became fully tonal. A fuller study of the segmental features with the proposed chronology in mind should further refine the history of Sinitic-Vietic language contact. Ideally, such historical linguistic information can inform ethnohistorians and archaeologists about human history in the region of northern Vietnam in the first millennium CE, the period of the end of the Dong Son archaeological culture and adoption and adaptation of Chinese culture.

\section{Acknowledgement}

I would like to thank Nathan Hill, Marc Miyake, and the two anonymous BCL reviewers for their very useful comments, suggestions, and corrections.

\section{References}

Alves, Mark J. 1995. Tonal features and the development of Vietnamese tones. Working Papers in Linguistics: Department of the University of Hawaii at Manoa Vol. 27:1-13.

Alves, Mark J. 2005. Sino-Vietnamese grammatical vocabulary and triggers for grammaticalization. In The 6th PanAsiatic International Symposium on Linguistics. Hanoi: Nhà Xuất Bản Khoa Học Xã Hội (Social Sciences Publishing House). $315^{-332 .}$

Alves, Mark J. 2016. Identifying Early Sino-Vietnamese Vocabulary via Linguistic, Historical, Archaeological, and Ethnological Data. Bulletin of Chinese Linguistics 9:264-295.

Alves, Mark J. 2018. Lịch sử của cộng (chữ hán là 共 - gòng) trong tiếng Việt [History of the word cộng (Chinese 共 - gòng) in Vietnamese]. Ngôn Ngũ 10 (2018):3-22.

Babaev, K. V. and I. V. Samarina. 2018. The May Language: Russian-Vietnamese Linguistic Expedition Materials, Release No. 5. Moscow: IAsk Publishing House.

Baxter, William H. 1992. A Handbook of Old Chinese Phonology. New York: Walter de Gruyter.

Baxter, William H. and Laurent Sagart. 2014. Baxter-Sagart Old Chinese reconstruction, version 1.1 (2o September 2014). Available online at http://ocbaxtersagart.lsait.lsa.umich.edu/BaxterSagartOCbyMandarinMC2014-09-20. pdf.

Brunelle, Marc and James Kirby. 2016. Tone and phonation in Southeast Asian languages. Language and Linguistics Compass 10.4:191-207.

Đào, Duy Anh. 1979. Chũ Nôm: nguồn gốc, cấu tạo, diễn biến [Chu Nom: origins, formation, and transformations]. Hà Nội: Nhà Xuất Bản Khoa Học Xã Hội.

Diffloth, Gérard. 1989. Proto-Austroasiatic creaky voice. Mon-Khmer Studies 15:139-54.

Enfield, Nick J. and Gerárd Diffloth. 2009. Phonology and sketch grammar of Kri, a Vietic language of Laos. Cahiers de Linguistique - Asie Orientale 38.1:3-69.

Ferlus, Michel. 1982. Spirantisation des obstruantes médiales et formation du système consonantique du vietnamien. Cahiers de Linguistique Asie Orientale 11.1:83-106.

Ferlus, Michel. 1998. Les systèmes de tons dans les langues viet-muong. Diachronica. Netherlands: John Benjamins, $1998,15.1: 1-27$.

Ferlus, Michel. 2004. The origin of tones in Viet-Muong. In Papers from the Eleventh Annual Meeting of the Southeast Asian Linguistics Society 20o1, ed. by Somsonge Burusphat, 297-313. Arizona State University. 
Haudricourt, André G. 1954a. Comment reconstruire le Chinois Archaïque. Word 10.2-3:351-364.

Haudricourt, André G. 1954b. De l'origine de la ton de Vietnamien.Journal Asiatique 242:69-82.

Higham, Charles F. W. 2017. First farmers in mainland Southeast Asia. Journal of Indo-Pacific Archaeology 41:13-21.

Jia, Fangzhi. n.d. Spreadsheet of possible Early Sino-Vietnamese items. Unpublished. Masaaki, Shimizu. 2015.

A Reconstruction of Ancient Vietnamese Initials Using Chu Nom Materials. NINJAL Research Papers 9:135-158.

Maspero, Henri. 1912. Etudes de phonetique historique de la langue annamite (Studies on the phonetic history of the Annamese language). Bulletin de l'École française d'Extrême- Orient XII.1.

Mei, Tsu-Lin. 1970. Tones and prosody in Middle Chinese and the origin of the rising tone. Harvard Journal of Asiatic Studies 30:86-110.

Nguyễn, Ngọc San. 2003. Tìm hiểu tiếng Việt lịch sủ̉ [Exploring the History of the Vietnamese Language]. Hanoi: Nhà Xuất Bản Đại Học Sư Phạm.

Nguyễn, Tài Cẩn. 1995. Gíao trình lịch sử ngũ âm tiếng Việt [Textbook of Vietnamese historical phonology]. Hà Nội : Nhà Xuất Bản Gíao Dục.

Nguyễn, Thanh Tùng. 2015. A study of the stratal corresponding relationship between Sino-Vietnamese and Chinese [漢越語和漢語的層次對應關係研究]. Taiwan: National Chung Hsing University. dissertation.

Nguyễn, Văn Lợi. 1993. Tiếng Rục [The Rục language]. Hà Nội: Nhà Xuất Bản Khoa Học Xã Hội.

Norquest, Peter. K. 2008. A Phonological Reconstruction of Proto-Hlai. Dissertation. The University of Arizona.

Phan, John Duong. 2013. Lacquered Words: The Evolution of Vietnamese under Sinitic Influences from the 1st Century $B C E$ through the 17th Century CE. Ithaca: Cornell University dissertation.

Pittayaporn, Pittayawat. 2009. The Phonology of Proto-Tai. Ph.D. Doctoral Dissertation. Cornell University.

Premsrirat, Suwilai. 1996. Phonological characteristics of So (Thavung), a Vietic language of Thailand. Mon-Khmer Studies 26:161-178.

Pulleyblank, Edwin G. 1962. The consonantal system of Old Chinese, Part ii. Asia Minor 9:206-265.

Pulleyblank, Edwin G. 1978. The nature of Middle Chinese tones and their development to early Mandarin.Journal of Chinese Linguistics 6.2:173-203.

Pulleyblank, Edwin G. 1981. Some notes on Chinese historical phonology. Bulletin de l'ecole Françoise d'ExtremeOrient 69:277-288.

Pulleyblank, Edwin G. 1984. Middle Chinese: a study in historical phonology. University of British Columbia Press.

Ratliff, Martha. 2010. Hmong-Mien Language History. Canberra, Australia: Pacific Linguistics. Sagart, Laurent. 1986. On the departing tone. Journal of Chinese Linguistics 14.1:90-113.

Sagart, Laurent. Glottalized tones in China and South-east Asia. In Prosodic Analysis and Asian Linguistics: to Honour R.K. Sprigg. Pacific Linguistics, C-104:83-93.

Schneider, Paul. 1992. Dictionnaire historique des ideogrammes Vietnamiens, Nice, France: Universite de NiceSophia Antipolis, Unité de Recherches Interdsciplinaires sur l'Asie du Sud Est, Madagascar et les Iles de l'Océan Indien.

Shorto, Harry L. 2006. A Mon-Khmer Comparative Dictionary. Canberra Pacific Linguistics 579.

Sidwell, Paul and Roger Blench. 2011. The Austroasiatic Urheimat: The Southeastern Riverine Hypothesis. In Dynamics of Human Diversity, ed. by Nick J. Enfield, 317-345. Canberra: Pacific Linguistics.

Taylor, Keith W. 1983. The birth of Vietnam. Berkeley: University of California Press.

Taylor, Keith W. 2013. A History of the Vietnamese (Cambridge Concise Histories). Cambridge University Press.

Thomason, Sarah Grey and Terrence Kaufman. 1988. Language contact, creolization, and genetic linguistics.

Berkeley: University of California Press.

Thurgood, Graham. 2002. Vietnamese and tonogenesis: revising the model and the analysis. Diachronica 19.2:333-363.

Ting, Pang-hsin. 丁邦新. 1981. 汉语声调源于韵尾说之检讨, 《汉学会议论文集》。267-283. 
Tryon, Ray. 1979. Sources of middle Chinese phonology: a prolegomenon to the study of Vietnamized Chinese. Southern Illinois University MA Thesis.

Vu, Duc Nghieu. 2019. Vietnamese Initial Consonant Clusters in Quốc Ngũ Documents from the 17th to Early 19th Centuries. JSEALS 12.1:143-162.

Vương, Lộc. 2002. Từ điển từ cổ [A dictionary of ancient words]. Da Nang, Vietnam: Nhà Xuất Bản Đà Nẵng, Trung Tâm Từ Điển Học.

Wang, Feng. 汪锋. 2006. 去声源于 *-s 尾假说之再检讨. Journal of Chinese Linguistics 34.1:1-24.

Wang, Li. 王力. 1948. 〈漢越語研究〉. 《嶺南學報》9.1:1-96。

Wang, Li. 王力. 1958. 〈漢越語研究〉.《漢語史論文集》。290-406。北京：科學出版社。

Yip, Moira. 2006. The symbiosis between perception and grammar in loanword phonology. Lingua 116.7:950-975.

Zhu, Xiaonong. 朱曉農. 2007. 〈證早期上聲帶假聲〉, 《中國語文》2:160-168.

Zhu, Xiaonong. 朱曉農. 2009.〈聲調起因於發聲：兼論漢語四聲的發明〉，《語言研究集 刊》，第六輯 1-29. 上海：上海辭書出版社。

Zhū, Xiǎonóng. 2015. Tonogenesis, in Encyclopedia of Chinese Language and Linguistics, General Editor Rint Sybesma. Consulted online on og November 2016 http://dx.doi.org/10.1163/2210-7363_ecll_COM_00ooo427. First published online: 2015 . 


\section{Appendix}

Caveat: The ESv items in Tables A through $\mathrm{K}$ are determined to be of Chinese origins with medium to high certainty. The degree of certainty is based on patterns of semantic and phonological properties in addition to consideration of the semantic domains of the words and nature of the sociocultural contact between Sinitic and Vietic speakers in the first millennium CE. The possibility of chance similarity remains, and in fact, it is possible that some of the items listed herein are not Chinese loanwords. Nevertheless, the weight of evidence in terms of the significant number of items identified, especially those which are more specifically tied to early Chinese culture, and the consistency of phonological patterns-as presented in Section-makes it likely that most, and potentially all, of the items herein are genuine early Chinese loanwords in Vietnamese.

TABLE A ESV hỏi in yinqu tone words, with segments differing from LSV counterparts

\begin{tabular}{|c|c|c|c|c|c|}
\hline GLOSS & CHINESE & OC & MC & ESV & LSV \\
\hline 1. order, to & 報 bào & ${ }^{*} \mathrm{p}^{\mathrm{S}} \mathrm{uk}-\mathrm{s}$ & pawH & bảo & báo \\
\hline 2. mustard plant & * jiè/gài & ${ }^{*} k^{\mathrm{S}} \mathrm{r}[\mathrm{e}][\mathrm{t}]-\mathrm{s}$ & keajH & cải & giới \\
\hline 3. transport & 載 zài & $*[\mathrm{ts}]^{\mathrm{S}} \partial \mathrm{\partial}-\mathrm{s}$ & tsojH & chở & tái \\
\hline 4. exchange, to & 兌/兑 duì & ${ }^{*} \mathrm{I}^{\mathrm{S}}$ ot-s & dwajH & dổi & đoái \\
\hline 5. marry, to & 嫁 jià & ${ }^{*} \mathrm{~s} . \mathrm{k}^{\mathrm{S}} \mathrm{ra}-\mathrm{s}$ & kaeH & gả & giá \\
\hline 6. chopped vegetables and meat & 膾 kuài & $\left.{ }^{*} \mathrm{C} .[\mathrm{k}]\right]^{\mathrm{S}}[\mathrm{o}][\mathrm{p}]-\mathrm{s}$ & kwajH & gỏi & khoái \\
\hline 7. to send & 寄 jì & ${ }^{*} \mathrm{C} .[\mathrm{k}](\mathrm{r}) \mathrm{aj}-\mathrm{s}$ & kjeH & gửi/gởi & ký \\
\hline 8. relate/tell, to & 計 jì & ${ }^{*} \mathrm{k}^{\mathrm{s}} \mathrm{ij}-\mathrm{s}$ & $\mathrm{kejH}$ & kể & kế \\
\hline 9. lure, to & 餌 ě r & *[C. $] \mathrm{n} ə(\mathrm{P})-\mathrm{s}$ & nyiH & nhử & $\mathrm{nh}$ \\
\hline 10. lungs & 肺 fèi & ${ }^{*} \mathrm{p}^{\mathrm{hS}}[\mathrm{a}][\mathrm{t}]-\mathrm{s}$ & phjojH & phổi & phế \\
\hline 11. measure for divinations & 卦 guà & ${ }^{*}[\mathrm{k}]^{\mathrm{wS}} \mathrm{re}-\mathrm{s}$ & kweaH & quẻ & quái \\
\hline 12. rabbit & 兔 tù & ${ }^{*}{ }_{0}^{\mathrm{S}} \mathrm{a}-\mathrm{s}$ & thuH & thỏ & thố \\
\hline 13. try, to & 試 shì & *l ə ək-s & syiH & thử & thí \\
\hline 14. express, to & 訴 sù & ${ }^{*} \mathrm{~s}-\eta^{\mathrm{S}} \mathrm{ak}-\mathrm{s}$ & $\mathrm{suH}$ & tỏ & tố \\
\hline $15 \cdot$ young & 稚 zhì & *Irəj-s & drijH & trẻ & trĩ \\
\hline 16. age & 歲 suì & ${ }^{*} \mathrm{~s}-\mathrm{q}^{\mathrm{wh}}$ at-s & sjwejH & tuổi & tuế \\
\hline
\end{tabular}

TABLE B ESV ngã in yangqu tone words, with segments differing from LSV counterparts

\begin{tabular}{|c|c|c|c|c|c|}
\hline GLOSS & CHINESE & OC & MC & ESV & LSV \\
\hline 1. bellow & 煒 bèi & NONE & NONE & bễ & bị \\
\hline 2. word (in writing) & 字 zì & ${ }^{*} \mathrm{~m} \partial-\mathrm{dz}$-s & $\mathrm{dziH}$ & chũ & tự \\
\hline 3. repair/treat, to & 治 zhì & *lrə-s & driH & chữa & trị \\
\hline 4. ride (a horse) & 騎 jì & $*[\mathrm{~g}](\mathrm{r}) \mathrm{aj}-\mathrm{s}$ & gje & cưỡi/cỡi & kị \\
\hline 5. also & 共 gòng & ${ }^{*} \mathrm{~N}-\mathrm{k}(\mathrm{r})$ on?-s & gjowngH & cũng & cộng \\
\hline 6. bag & 袋 dài & ${ }^{*}$ Cə.l' ${ }^{\text {` }}$ k $-\mathrm{s}$ & dojH & đãy & đại \\
\hline 7. easy & 易 yì & *lek-s & yeH & dễ & dị \\
\hline
\end{tabular}


TABLE B ESV ngã in yangqu tone words, with segments differing from LSV counterparts (cont.)

\begin{tabular}{|c|c|c|c|c|c|}
\hline GLOSS & CHINESE & OC & MC & ESV & LSV \\
\hline 8. chopsticks & 箸 zhù & ${ }^{*} \mathrm{~d}<\mathrm{r}>\mathrm{ak}-\mathrm{s}$ & drjoH & đũa & trợ \\
\hline 9. thank; take leave, to & 謝 xiè & *sə-lAk-s & zjaeH & giã & tạ \\
\hline 10. interest (financial) & 利 lì & ${ }^{*}$ C.ri $[t]-s$ & $\mathrm{lijH}$ & lãi & lợi \\
\hline 11. confused & 亂 luàn & ${ }^{*}[\mathrm{r}]^{\mathrm{S}} \mathrm{O}[\mathrm{n}]-\mathrm{s}$ & lwanH & lẫn & loạn \\
\hline 12. prominent & 露 lù & ${ }^{*}$ p.r rak-s $^{\text {S }}$ & luH & lõ & lộ \\
\hline 13. hat & 帽 mào & ${ }^{*} \mathrm{~m}^{\mathrm{f}} \mathrm{uk}-\mathrm{s}$ & mawH & mũ & mạo \\
\hline 14. go on foot, walk, to & 步 bù & ${ }^{*} \mathrm{~m} ə-\mathrm{b}^{\mathrm{f}} \mathrm{a}-\mathrm{s}$ & buH & vã & bộ \\
\hline 15. draw/paint, to & 畫/劃 huà & ${ }^{*} \mathrm{C}-\mathrm{g}^{w S}$ rek-s & hweaH & vẽ & họa \\
\hline
\end{tabular}

TABLE C ESV ngã in yangqu tone words, with segments the same as in LSV counterparts

\begin{tabular}{llllll}
\hline GLOSS & CHINESE & OC & MC & ESV & LSV \\
\hline 1. fierce (of a storm) & 暴 bào & ${ }^{*}[\mathrm{~b}]^{\mathrm{S}}$ awk-s & bawH & bão & bạo \\
2. small shrine & 廟 miào & ${ }^{*}[\mathrm{~m}]$ raw-s & mjewH & miễu & miếu \\
3. two & 二 èr & ${ }^{*}$ ni $[\mathrm{j}]-\mathrm{s}$ & nyijH & nhĩ & nhị \\
4. think, to & 議 yì & ${ }^{*} \mathrm{y}(\mathrm{r})$ aj-s & ngjeH & nghĩ & nghị \\
\hline
\end{tabular}

TABLE D ESV sắc in yinshang tone words, with segments differing from LSV counterparts

\begin{tabular}{|c|c|c|c|c|c|}
\hline GLOSS & CHINESE & OC & MC & ESV & LSV \\
\hline 1. precious & 寶 băo & ${ }^{*} \mathrm{p}^{\mathrm{c}} \mathrm{u} ?$ & pawX & báu & bảo \\
\hline 2. hammer, axe & 斧 fǔ & ${ }^{*} \mathrm{p}(\mathrm{r}) \mathrm{a} ?$ & pjuX & búa & phủ \\
\hline 3. noodles & 粉 fěn & *mə.pən? & pjunX & bún & phấn \\
\hline 4. dip into liquid, to & 䅇 zhàn & NONE & NONE & chấm & trám \\
\hline 5. behead, to & 斬 zhăn & ${ }^{*}[\mathrm{ts}] \mathrm{ram} ?$ & tsreamX & chém & trảm \\
\hline 6. cup (small bowl) & 盍 zhăn & $*[\mathrm{ts}] \mathrm{rar} ?$ & tsreanX & chén & trản \\
\hline 7. lord & 主 zhǔ & $*$ to? & tsyuX & chúa & chủ \\
\hline 8. contain, to & 貯 zhù & NONE & NONE & chứa & trử \\
\hline 9. bow, prostrate oneself, to & 跪 guř & ${ }^{*}[\mathrm{~g}](\mathrm{r}) \mathrm{oj}$ ? & gjweX & cúi & quị \\
\hline 10. hit, to & 打 dǎ & NONE & (děng) & đánh & đả \\
\hline 11. bottom & 底 dǐ & ${ }^{*} \mathrm{t}^{\mathrm{i}_{\mathrm{ij}}} \mathrm{P}$ & tejX & đáy & để \\
\hline 12. count, to & 點 diăn & ${ }^{*} \mathrm{t}^{\mathrm{f}} \mathrm{em} ?$ & temX & đếm & điểm \\
\hline 13. cover up, to & 奄 yǎn & $*$ ?(r)om? & 'jemX & ém & yểm \\
\hline 14. brocade/embroidered silk & 錦 jǐn & ${ }^{*} \mathrm{C} . \mathrm{k}(\mathrm{r})[\partial] \mathrm{m} ?$ & $\operatorname{kimX}$ & gấm & cẩm \\
\hline 15. chair & 几/機 jī & ${ }^{*} \mathrm{C} . \mathrm{kr}[\partial] \mathrm{j} ?$ & kijX & ghế & kỷ \\
\hline 16. careful & 謹 jǐn & ${ }^{*} \mathrm{k} \partial[\mathrm{r}] \mathrm{P}$ & $k j+n X$ & ghín & cẩn \\
\hline
\end{tabular}


TABLE D ESV sắc in yinshang tone words, with segments differing from LSV counterparts (cont.)

\begin{tabular}{|c|c|c|c|c|c|}
\hline GLOSS & CHINESE & $\mathrm{OC}$ & MC & ESV & LSV \\
\hline 17. paper & 紙 zhǐ & *k.te? & tsyeX & giấy & chỉ \\
\hline 18. well & 井 jǐng & ${ }^{*}$ C.tsey? & tsjengX & giếng & tỉnh \\
\hline 19. type & 種 zhǒng & *k.top? & tsyowngX & giống & chủng \\
\hline 20. widowed & 寡 guǎ & ${ }^{*}[\mathrm{C} . \mathrm{k}]^{\mathrm{wS}} \mathrm{ra?}$ & kwaeX & góa & quả \\
\hline 21. wrap, to & 寡/裏 guă & ${ }^{*}[\mathrm{C} . \mathrm{k}]^{\mathrm{wS}} \mathrm{ra} ?$ & kwaX & gói & quả, khoả \\
\hline 22. mussel & 蜆 xiăn & NA & NA & hến & hiện \\
\hline 23. lacking & 減 jiǎn & ${ }^{*} \mathrm{k}^{\mathrm{S}} \mathrm{r}[\partial] \mathrm{m} ?$ & keamX & kém & giảm \\
\hline 24. cocoon & 茳困 jiàn & ${ }^{*} \mathrm{k}^{\mathrm{S}} \mathrm{en} ?$ & kenX & kén & kiển \\
\hline 25. choose, to & 揀, 柬 jiǎn & ${ }^{*} k^{\complement} r[a] n ?$ & keanX & kén & giản \\
\hline 26. scissors & 鉸 jiǎo & ${ }^{*} \mathrm{~m} ә-[\mathrm{k}]^{\mathrm{s}} \mathrm{r}[\mathrm{a}] \mathrm{w} ?$ & kaewX & kéo & giảo \\
\hline 27. difficult & 苦 kǔ & ${ }^{*} \mathrm{k}^{\mathrm{hS} \mathrm{a}} \mathrm{P}$ & khuX & khó & khổ \\
\hline 28. agree/accept, to & 肯 kěn & 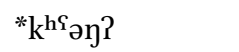 & khongX & khứng & khẳng \\
\hline 29. secretive & 謹 jǐn & ${ }^{*} \mathrm{k} \partial[\mathrm{r}] ?$ & $k j+n X$ & kín & cẩn \\
\hline 30. rudder/helm & 舵 duò & ${ }^{*} \mathrm{I}_{\mathrm{\Upsilon}}^{\mathrm{aj}} \mathrm{P}$ & $\mathrm{daX}$ & lái & đà \\
\hline 31. paddy & 稻 dào & $*[1]^{\mathrm{s}} \mathrm{u} ?$ & dawX & lúa ${ }^{15}$ & đạo \\
\hline 32. dance, to & 舞 wǔ & *k.m(r)a? & mjuX & múa & vũ \\
\hline 33. rootstock of lotus & 藕 ǒu & ${ }^{*} \mathrm{C} . \eta^{\mathrm{S}}(\mathrm{r}) \mathrm{o} ?$ & nguwX & ngó & ngẫu \\
\hline 34. tile & 瓦 wǎ & ${ }^{*} \mathrm{C} . \eta^{\mathrm{w}} \mathrm{r} \mathrm{ra}[\mathrm{j}] ?$ & ngwaeX & ngói & ngoã \\
\hline 35. catch; be infected by & 染 răn & ${ }^{*}$ C.n[a]m? & nyemX & nhuốm & nhiễm \\
\hline 36. dry & 燥 zào & ${ }^{*}$ C.s ${ }^{\text {S }}$ aw? & sawX & ráo & táo \\
\hline 37. lacking/little & 少 shăo & *[s.t] ew? & syewX & thiếu & thiểu \\
\hline 38. tub & 桶 tǒng & ${ }^{*}{ }_{0}^{\mathrm{s}} \mathrm{oj} ?$ & thuwngX & thống & dũng \\
\hline 39. 1st earthly branch (rat) & 子 zì & $*[\mathrm{ts}] \partial ?$ & tsiX & tí & tử \\
\hline 40. purple & 紫 zǐ & NONE & NONE & tiá & tử \\
\hline 41. mend, to & 補 bǔ & ${ }^{*}[\mathrm{Cə}]-\mathrm{p}^{\complement} \mathrm{a} ?$ & $\mathrm{puX}$ & vá & bổ \\
\hline 42. board/plank & 板, 版 băn & ${ }^{*}$ C.p $p^{\mathrm{S}}$ ran? & paenX & ván & bản \\
\hline 43. thigh & 髀 bì & *pe? & pjieX & vế & bế \\
\hline 44. compare, to & 比 bǐ & ${ }^{*}$ C.pij & pjijX & ví & tỷ \\
\hline 45. capital/funds & 本 běn & ${ }^{*} \mathrm{C} . \mathrm{p}^{\mathrm{S}} \partial[\mathrm{n}] ?$ & pwonX & vốn & bổn, bản \\
\hline 46. ugly, bad & 醜 chǒu & ${ }^{*}$ t.q ${ }^{\mathrm{h}} \mathrm{u} ?$ & tsyhuwX & xấu & xú \\
\hline
\end{tabular}

15 One reviewer commented on the seeming disparity of the rhyme. However, the diphthongization from * $u$ to [uə] is a common feature of ESV. 
TABLE E ESV sắc in yinshang tone words, with the same segments as $S V$ counterparts

\begin{tabular}{|c|c|c|c|c|c|}
\hline GLOSS & CHINESE & OC & MC & ESV & LSV \\
\hline 1. light, glare & 影 yǐng & *qraj? & jaengX & ánh & ảnh \\
\hline 2. feeling & 感 găn & ${ }^{*} \mathrm{k}^{\mathrm{S}}[\partial] \mathrm{m} ?$ & komX & cám & cảm \\
\hline 3. kick, to & 打 dă & NONE & NONE & đá & đả \\
\hline 4. peck of & 斗 dǒu, dòu & ${ }^{*} \mathrm{t}^{\mathrm{S}} \mathrm{O} ?$ & tuwX & đấu & đẩu; đấu \\
\hline 5. bet, to & 賭 dǔ & ${ }^{*} \mathrm{~m} ə . \mathrm{t}^{\mathrm{S}} \mathrm{a}$ ? & tuX & đố & đổ \\
\hline 6. if/supposing & 假 jiǎ & ${ }^{*}$ Cə.k ${ }^{\mathrm{S}} \mathrm{ra?}$ & kaeX & gía & giả \\
\hline 7. rather, very & 可 kě & ${ }^{*}[\mathrm{k}]^{\mathrm{hS}} \mathrm{a}[\mathrm{j}] \mathrm{P}$ & khaX & khá & khả \\
\hline 8. pray/promise, to & 懇 kěn & NONE & NONE & khấn & khẩn \\
\hline 9. order/bid, to & 遣 qiǎn & ${ }^{*}[\mathrm{k}]{ }^{\mathrm{h}} \mathrm{e}[\mathrm{n}] ?$ & khjienX & khiến & khiển \\
\hline 10. bright/shiny & 朗 lǎng & ${ }^{*} \mathrm{k} . \mathrm{r}^{\mathrm{C}} \mathrm{a}$ ? & langX & láng & lãng16 \\
\hline 11. scrawling & 草 cǎo & $*\left[\mathrm{ts}^{\mathrm{h}}\right]^{\mathrm{s}} \mathrm{u} ?$ & tshawX & tháu & thảo \\
\hline 12. order/bid, to & 遣 qiăn & ${ }^{*}[\mathrm{k}]{ }^{\mathrm{h}} \mathrm{e}[\mathrm{n}] ?$ & khjienX & khiến & khiển \\
\hline 13. parasol & 傘 săn & $*[\mathrm{~s}]^{\mathrm{S}} \operatorname{ar} ?$ & $\operatorname{san} X$ & tán & tản \\
\hline
\end{tabular}

TABLE F ESV nặng in yangshang tone words, with segments differing from LSV counterparts

\begin{tabular}{|c|c|c|c|c|c|}
\hline GLOSS & CHINESE & $\mathrm{OC}$ & MC & ESV & LSV \\
\hline 1. register book & 簿 bù & $*[b]^{\mathrm{S} a} ?$ & buX & bạ & bộ \\
\hline 2. plait, to & 辫 biàn & ${ }^{*} \mathrm{~m}-\mathrm{p}^{\mathrm{f}} \mathrm{e}[\mathrm{r}] ?$ & benX & bện & biện \\
\hline 3. widowed & 婦 fù & *mə.bə? & bjuwX & bụa & phụ \\
\hline 4. father's younger brother & 舅 jiù & ${ }^{*}[\mathrm{~g}](\mathrm{r}) \mathrm{u} ?$ & gjuwX & cậu & cũu \\
\hline 5. sister, older & 姊 zǐ & ${ }^{*}[\mathrm{ts}][\mathrm{i}] \mathrm{j} ?$ & tsijX & chị & tỉ \\
\hline 6. market & 市 shì & ${ }^{*} \mathrm{C} .[\mathrm{d}] \partial ?$ & dzyiX & chợ & thị \\
\hline 7 . select & 選 xuăn & $*[\mathrm{~s}] \mathrm{o}[\mathrm{n}] ?$ & sjwenX & chọn & tuyển \\
\hline 8. spur (of rooster) & 距 jù & NONE & NONE & cựa & cự \\
\hline 9. stomach & 肚 dù & ${ }^{*} \mathrm{~m}-\mathrm{t}^{\mathrm{S}} \mathrm{a} ?$ & $\mathrm{duX}$ & dạ & đỗ \\
\hline 10. wait, to & 待 dài & $*[\mathrm{~d}]^{\mathrm{\varsigma}} \partial \mathrm{P}$ & $\operatorname{doj} X$ & đợi & đãi \\
\hline 11. stepfather & 丈 zhàng & $*[\mathrm{~d}] \mathrm{ray} ?$ & drjangX & dượng & trượng \\
\hline 12. appointment & 限 xiàn & ${ }^{*}[\mathrm{~g}]^{\mathrm{S}} \operatorname{r\partial }[\mathrm{n}] ?$ & heanX & hẹn & hạn \\
\hline 13. family name & 戶 hù & ${ }^{*} \mathrm{~m}-\mathrm{q}^{\mathrm{S}} \mathrm{a} ?$ & huX & họ & hộ \\
\hline 14. tael & 量 liàng & ${ }^{*}[\mathrm{r}] \mathrm{an}-\mathrm{s}$ & ljangX & lạng & lượng \\
\hline 15. kowtow, to & 禮 lǐ & ${ }^{*}[\mathrm{r}]^{\mathrm{S}_{\mathrm{ijj}}} \mathrm{P}$ & lejX & lạy & lễ \\
\hline 16. silk & 縷 lü & $*[\mathrm{r}] \mathrm{o} ?$ & $\operatorname{ljuX}$ & lụa & lũ \\
\hline
\end{tabular}

16 The low register tone on this word in the LSv layer cannot be readily explained, but this tone still belongs to the shangsheng tone category. 
TABLE F ESV nặng in yangshang tone words, with segments differing from LSV counterparts (cont.)

\begin{tabular}{|c|c|c|c|c|c|}
\hline GLOSS & CHINESE & OC & MC & ESV & LSV \\
\hline 17. gather, to & 斂 liǎn & $*[\mathrm{r}][\mathrm{a}] \mathrm{m} ?$ & $\operatorname{ljemX}$ & lượm & liễm \\
\hline 18. seedling & 米 mǐ & $*(\mathrm{C}.) \mathrm{m}^{\mathrm{q}}[\mathrm{e}] \mathrm{j} \mathrm{P}$ & mejX & mạ & mễ \\
\hline 19. net & 網 wăng & *man? & mjangX & mạng & võng \\
\hline 20. strong & 猛 měng & NONE & NONE & mạnh & mãnh \\
\hline 21. 4th earthly branch (rabbit) & 卯 mǎo & ${ }^{*} \mathrm{~m}^{\mathrm{q}} \mathrm{ru}$ & maewX & mẹo & mão \\
\hline 22. mother's younger brother's wife & 姆 mǔ & *mə? & muwX & mợ & mố \\
\hline 23. every & 每 měi & ${ }^{*} \mathrm{~m}^{\complement} \partial ?$ & mwojX & mọi & mỗi \\
\hline 24. late & 晚 wăn & ${ }^{*} \mathrm{~m}[\mathrm{o}][\mathrm{r}] \mathrm{P}$ & mjonX & muộn & vãn \\
\hline 25. dye/infect, to & 染 răn & ${ }^{*} \mathrm{C} . \mathrm{n}[\mathrm{a}] \mathrm{m} ?$ & nyemX & nhuộm & nhiễm \\
\hline 26. stamen, pistil & 芯 ruǐ & NA & NA & nhụy & nhị \\
\hline 27. wine/alcohol & 酉 yǒu & *N-ru? & yuwX & rượu & dậu \\
\hline 28. expert & 士 shì & ${ }^{*}[\mathrm{~m}-\mathrm{s}-] \mathrm{rə} ?$ & dzriX & thợ & sĩ \\
\hline 29. resemble, to & 似 sì & *sə.lə? & ziX & tợ & tự \\
\hline 30. foreword & 序 xù & *[sə.l]a? & zjoX & tựa & tự \\
\hline 31. misfortune & 禍 huò & ${ }^{*}[g]^{w S}$ aj? & hwaX & vạ & họa \\
\hline 32. wife & 婦 fù & *mə.bə? & bjuwX & vợ & phụ \\
\hline
\end{tabular}

Note: Many of the LSV items in Table F have the năng tone (and in Mandarin, many have the fourth tone, typically for qusheng, not shangsheng words), suggesting no change between ESv and LSV. However, these are all formally considered shangsheng words in the Guangyun rhyme dictionary and are reconstructed with the expected final glottal stops. LSv vocabulary shows the phenomenon of quánzhuō shăng biàn qù 全濁上變去, also seen in many of the Mandarin items as well. See Phan (2013:92-93) for background historical linguistic research on this issue.

TABLE G ESV nặng in yangshang tone words, with the same segments as LSV counterparts

\begin{tabular}{llllll}
\hline GLOSS & CHINESE & OC & MC & ESV & LSV \\
\hline 1. cold & 冷 lěng & NONE & NONE & lạnh & lãnh \\
2. receive, acknowledge & * rěn & ${ }^{*}$ nə[n]? & nyinX & nhận & nhẫn
\end{tabular}


TABLE H ESV ngang in yingqu tone words, with segments differing LSV counterparts

\begin{tabular}{|c|c|c|c|c|c|}
\hline GLOSS & $\mathrm{CH}$ & OC & MC & ESV & LSV \\
\hline 1. leopard & 豹 bào & ${ }^{*} p^{\mathrm{S}} \mathrm{r}[\mathrm{e}] w \mathrm{k}-\mathrm{s}$ & paewH & beo & báo \\
\hline 2. sell & 販 fàn & NONE & NONE & buôn & phán \\
\hline 3. release & 放 fàng & *pay-s & pjangH & buông & phóng \\
\hline 4. abstain, to & 戒 jiè & ${ }^{*} \mathrm{k}^{\mathrm{S}}$ rək-s & keajH & cai & giới \\
\hline 5. admonish & 諫 jiàn & ${ }^{*} \mathrm{k}^{\mathrm{S}} \operatorname{ran} \mathrm{P}(-\mathrm{s})$ & kaenH & can & gián \\
\hline 6. saw (n.) & 鋸 jù & ${ }^{*} \mathrm{k}(\mathrm{r}) \mathrm{a}-\mathrm{s}$ & $\mathrm{kjoH}$ & cưa & cứ \\
\hline 7. crowded, numerous & 眾 zhòng & *tuy-s & tsyuwngH & đông & chúng \\
\hline 8. air; gas & 氣 qì & ${ }^{*}$ C.q ${ }^{\mathrm{h}} ә \mathrm{p}-\mathrm{s}$ & $\mathrm{khj}+\mathrm{jH}$ & hơi & khí \\
\hline 9. seal; to print & 印 yìn & *[?]in-s & jinH & in & ấn \\
\hline 10. shout/call & 叫 jiào & ${ }^{*} \mathrm{k}^{\mathrm{S}}$ ewk-s & kewH & kêu & khiếu \\
\hline 11. respect (in compounds) & 敬 jìng & ${ }^{*} \operatorname{krey}(\mathrm{P})-\mathrm{s}$ & kjaengH & kiêng & kính \\
\hline 12. familiar with & 慣 guàn & ${ }^{*} \mathrm{k}^{\mathrm{S}} \mathrm{ro}[\mathrm{n}]-\mathrm{s}$ & kwaenH & quen & quán \\
\hline 13. shout; announce & 譟 zào & ${ }^{*}$ C.s ${ }^{\mathrm{S}}$ aw-s & sawH & rao & táo \\
\hline 14. pardon, to & 赦 shè & $*[1]$ Ak-s & syaeH & tha & xá \\
\hline 15. substitute, to & 替 tì & ${ }^{*}{ }_{0} S_{i}[t]-s$ & thejH & thay & thế \\
\hline 16. embroider & 繡 xiù & ${ }^{*}[\mathrm{~s}] \operatorname{iw}(\mathrm{k})-\mathrm{s}$ & sjuwH & thêu & tú \\
\hline 17. to temper (of steel) & 焠 cùi & ${ }^{*}\left[\mathrm{ts}^{\mathrm{h}}\right]^{\mathrm{s}} \mathrm{u}[\mathrm{t}]-\mathrm{s}$ & tshwojH & tôi & thối \\
\hline
\end{tabular}

TABLE I ESV ngang in yinqu tone words, with the same segments as LSV counterparts

\begin{tabular}{|c|c|c|c|c|c|}
\hline GLOSS & $\mathrm{CH}$ & OC & MC & ESV & LSV \\
\hline 1. dish/bowl/pot; crock & 盍 àng & NONE & NONE & ang & áng \\
\hline 2. help/save, to & 救 jiù & ${ }^{*} \mathrm{~s} . \mathrm{k}(\mathrm{r}) \mathrm{u}-\mathrm{s}$ & kjuwH & cưu & cứu \\
\hline 3. belt & 帶 dài & ${ }^{*} \mathrm{C} . \mathrm{t}^{\mathrm{S}} \mathrm{a}[\mathrm{t}]-\mathrm{s}$ & tajH & đai & đái \\
\hline 4. freeze, to & 凍 dòng & ${ }^{*} \mathrm{t}^{\mathrm{S}} \mathrm{o \eta}-\mathrm{s}$ & tuwngH & đông & đống \\
\hline 5. encourage; advise & 勸 quàn & ${ }^{*}$ C.q ${ }^{\text {wh }}$ ar-s & khjwonH & khuyên & khuyến \\
\hline 6. sesame & 麻 má & ${ }^{*} \mathrm{C} . \mathrm{m}^{\mathrm{S}} \mathrm{raj}$ & mae & mè & ma \\
\hline 7. manure & 凟 fèn & ${ }^{*} \mathrm{p}[\mathrm{u}] \mathrm{r}-\mathrm{s}$ & pjunH & phân & phấn \\
\hline 8. report to king & 奏 zòu & ${ }^{*} \operatorname{ts}^{\mathrm{S}} \mathrm{O}(\mathrm{P})-\mathrm{s}$ & tsuwH & tâu & tấu \\
\hline 9. calculate & 算 suàn & ${ }^{*}[\mathrm{~s}]^{\mathrm{f}}$ or?-s & swanH & toan & toán \\
\hline 10. coal/charcoal & 炭 tàn & ${ }^{*}\left[\mathrm{t}^{\mathrm{h}}\right]^{\mathrm{S}} \mathrm{a}[\mathrm{n}]-\mathrm{s}$ & thanH & than & thán \\
\hline 11. sigh; lament & 嘆 tàn & ${ }^{*} \mathrm{n}_{0} \mathrm{~S}$ ar-s & thanH & than & thán \\
\hline 12. truthful; believe & 信 xìn & ${ }^{*}$ s-ni[n]-s & $\sin H$ & $\operatorname{tin}$ & tín \\
\hline 13. four & 四 sì & ${ }^{*}$ s.li $[\mathrm{j}]-\mathrm{s}$ & $\mathrm{sijH}$ & tư & tứ \\
\hline 14. news (Ch. 'ask') & 訊 xùn & ${ }^{*}[\mathrm{~s}] \mathrm{i}[\mathrm{n}]-\mathrm{s}$ & $\sin \mathrm{H}$ & $\operatorname{tin}$ & tấn \\
\hline 15. measure for pictures & 幀 zhēn & NONE & NONE & $\operatorname{tranh}$ & tránh \\
\hline
\end{tabular}


TABLE J ESV huyền in yangqu tone words, with segments differing from LSV counterparts

\begin{tabular}{|c|c|c|c|c|c|}
\hline GLOSS & $\mathrm{CH}$ & OC & MC & ESV & LSV \\
\hline 1. then & 便 biàn & *ben-s & bjienH & bèn & tiện \\
\hline 2. oar (archaic) & 棹 zhào & NONE & NONE & chèo & trạo \\
\hline 3. manner, appearance & 樣 yàng & NA & $\mathrm{NA}$ & dường & dạng \\
\hline 4. be addicted & 健 jiàn & NA & NA & ghiền & kiện \\
\hline 5. summer & 夏 xià & $*[\mathrm{G}]^{\mathrm{S}} \mathrm{ra?}$ & haeH & hè & hạ \\
\hline 6. cheap/low/mean & 賤 jiàn & $*[\mathrm{dz}][\mathrm{a}][\mathrm{n}]-\mathrm{s}$ & dzjenH & hèn & tiện \\
\hline 7. big junk (boat) & 艋 měng & NONE & NONE & mành & mãnh \\
\hline 8. marvelous; miraculous & 妙 miào & ${ }^{*}[\mathrm{~m}] \mathrm{ew}(\mathrm{P})-\mathrm{s}$ & mjiewH & mầu & diệu \\
\hline 9. wait for, desire & 望 wàng & *may-s & mjangH & mòng & vọng \\
\hline 10. fog; mist & 霧 wù & *kə.mok-s & mjuH & mù & vụ \\
\hline 11. taste (n.); smell & 味 wèi & *mət-s & $m j+j H$ & mùi & vị \\
\hline 12. ten thousand & 萬 wàn & ${ }^{*} \mathrm{C} . \mathrm{ma}[\mathrm{n}]-\mathrm{s}$ & mjonH & muôn & vạn \\
\hline 13. branch & 梗 gěng & ${ }^{*} \mathrm{k}^{\mathrm{S}} \mathrm{ran} ?$ & kaengX & ngành & ngạnh \\
\hline 14. profession & 藝 yì & *yet-s & ngjiejH & nghề & nghệ \\
\hline 15. prevent & 禦 yù & ${ }^{*} \mathrm{~m}-\mathrm{q}^{\mathrm{h}}(\mathrm{r}) \mathrm{a}$ ? & ngjoX & ngừa & ngự \\
\hline 16. moisten, to & 潤 rùn & NA & NA & nhuần & nhuận \\
\hline 17. smelt/forge & 鍊 liàn & $*[r]^{\mathrm{S}} \mathrm{en}-\mathrm{s}$ & lenH & rèn & luyện \\
\hline 18. leak, to & 漏 lòu & ${ }^{*}[\text { No-r }]^{\mathrm{s}}$ ok-s & luwH & rò & lậu \\
\hline 19. control oneself; check oneself & 慎 shén & $*[\mathrm{~d}] \mathrm{i}[\mathrm{n}]-\mathrm{s}$ & dzyinH & thìn & thận \\
\hline
\end{tabular}

TABLE K ESV Nouns and Verbs with huyền in yangqu tone words, with the same segments as LSV counterparts

\begin{tabular}{|c|c|c|c|c|c|}
\hline GLOSS & $\mathrm{CH}$ & OC & MC & ESV & LSV \\
\hline 1. use, to & 用 yòng & ${ }^{*} \mathrm{~m} . \mathrm{loy}-\mathrm{s}$ & yowngH & dung & dụng \\
\hline 2. jaw, chin & 領 hàn & ${ }^{*}[\mathrm{G}]^{\mathrm{S}}[\partial] \mathrm{m} ?$ & hom $X^{17}$ & hàm & hạm \\
\hline \multicolumn{2}{|c|}{$\begin{array}{l}\text { 3. pole/stake to block invading 捍 hàn } \\
\text { ships }\end{array}$} & ${ }^{*} \mathrm{~m}-\mathrm{k}^{\mathrm{S}} \mathrm{a}[\mathrm{r}]-\mathrm{s}$ & hanH & hàn & hãn \\
\hline 4. important & * xì & ${ }^{*} \mathrm{k}^{\mathrm{S}} \mathrm{ek}-\mathrm{s}$ & kejH & hề & hệ \\
\hline 5. category & 類 lèi & $*[r] \mathrm{u}[\mathrm{t}]-\mathrm{s}$ & lwijH & loài & loại \\
\hline 6. interest (financial) & 利 lì & ${ }^{*}$ C.ri $[t]-s$ & lijH & lời & lợi \\
\hline 7. curtain; screen & 幔 màn & ${ }^{*} \mathrm{~m}^{\mathrm{S}} \mathrm{a}[\mathrm{n}]-\mathrm{s}$ & manH & màn & mạn \\
\hline 8. big junk (boat) & 艋 měng & NONE & NONE & mành & mãnh \\
\hline 9. art/skill & 藝 yì & *yet-s & ngjiejH & nghề & nghệ \\
\hline
\end{tabular}

\footnotetext{
17 Though this item is labelled with X, and hence a shangsheng tone, following Baxter and Sagart (2014), this item is labelled a qusheng tone in the later Guangyun rhyme dictionary. It is thus unsurprising that this item, as well as toà 'building (clsf)', have the same segments as in LSV as they are relatively later loans.
} 
TABLE K ESV Nouns and Verbs with huyền in yangqu tone words, with the same segments as LSV counterparts (cont.)

\begin{tabular}{|c|c|c|c|c|c|}
\hline GLOSS & $\mathrm{CH}$ & $\mathrm{OC}$ & MC & ESV & LSV \\
\hline 10. outside & 外 wài & ${ }^{*}[\mathrm{y}]^{\mathrm{wS}} \mathrm{a}[\mathrm{t}]-\mathrm{s}$ & ngwajH & ngoài & ngoại \\
\hline 11. wish; promise & 願 yuàn & ${ }^{*}[\mathrm{y}] \mathrm{o}[\mathrm{n}]-\mathrm{s}$ & ngjwonH & nguyền & nguyện \\
\hline 12. moisten, to & 潤 rùn & NA & NA & nhuần & nhuận \\
\hline 13. yield & 讓 ràng & *nay-s & nyangH & nhường & nhượng \\
\hline 14. sentiment & 念 niàn & ${ }^{*} n^{\mathrm{S}} \mathrm{im}-\mathrm{s}$ & nemH & niềm & niệm \\
\hline 15. alloted duty; part & 分 fèn & ${ }^{*}[\mathrm{~m}]-\mathrm{p} ə[\mathrm{n}]-\mathrm{s}$ & pjunH & phần & phận \\
\hline 16. swear & 誓 shì & $*[\mathrm{~d}][\mathrm{a}] \mathrm{t}-\mathrm{s}$ & dzyejH & thề & thệ \\
\hline 17. left over & 剩 shèng & ${ }^{*}$ Cə.ləク-s & zyingH & thừa & thựa \\
\hline 18. building (clsf) & 座 zuò & ${ }^{*}[\mathrm{dz}]^{\mathrm{s}} \mathrm{o}[\mathrm{j}] \mathrm{P}-\mathrm{s}$ & dzwaX ${ }^{18}$ & toà & toạ \\
\hline 19. self; from & 自 zì & *s. [b]i[t] $-\mathrm{s}$ & dzijH & từ & tự \\
\hline 20. ten thousand & 萬 wàn & ${ }^{*}$ C.ma $[\mathrm{n}]-\mathrm{s}$ & mjonH & vàn & vạn \\
\hline 21. rhyme & 韻 yùn & ${ }^{*}\left[\mathrm{~m}-\mathrm{q}^{\mathrm{w}}\right]<\mathrm{r}>\mathrm{i}[\mathrm{n}]-\mathrm{s}$ & hwinH & vần & vận \\
\hline 22. for; because & 為 wèi & ${ }^{*} \mathrm{G}^{\mathrm{w}}(\mathrm{r}) \mathrm{aj}-\mathrm{s}$ & hjweH & vì & vị \\
\hline
\end{tabular}

18 See footnote 16 for details about the tone category. 


\section{早期漢越詞匯數據與漢語越語聲調發展的相關年表}

\section{歐邁強}

蒙哥馬利學院

\section{提要}

越南語有許多早期的漢語借詞，其中有一層有越南的 ngang 和 huyền 聲（相當於漢語的平 聲）但卻應該有 sắc 和 nặng 聲 (相當於去聲) 。我們提出, 這一早期漢越詞的层是上古漢語 的 ${ }^{*}$ s 已失去的和越芒语支

（Viet-Muong）声调发生之前的外來詞，因此在越芒语支聲調發 生時，產生有平聲的詞。本文提供六十個 早期漢越的例子，這些例證在去聲詞有 ngang/huyền 聲的現象，但也有一百二十個例子例證早期和後期漢越 此之間的 sắc/nặng 和 hỏi/ngã 聲調逆轉。總之, 這些证据供給在漢語支（Sinitic）和越語支（Vietic）中發展聲 調的總 體相對年表。

\section{關鍵詞}

漢越詞、漢語外來詞、聲調起因和發展 